\title{
Mechanisms and clinical behavior of hepatocellular carcinoma in HBV and HCV infection and alcoholic and non-alcoholic fatty liver disease
}

\author{
Riccardo Nevola, Luca Rinaldi, Mauro Giordano, Aldo Marrone, Luigi Elio Adinolfi \\ Department of Medical, Surgical, Neurological, Metabolic, and Geriatric Sciences, University of Campania "L. Vanvitelli", Division of \\ Internal Medicine, Piazza Miraglia, Naples 80138, Italy.
}

Correspondence to: Prof. Luigi Elio Adinolfi, Department of Medical, Surgical, Neurological, Metabolic, and Geriatric Sciences, University of Campania "L. Vanvitelli", Division of Internal Medicine, Piazza Miraglia, Naples 80138, Italy. E-mail: luigielio.adinolfi@unicampania.it

How to cite this article: Nevola R, Rinaldi L, Giordano M, Marrone A, Adinolfi LE. Mechanisms and clinical behavior of hepatocellular carcinoma in HBV and HCV infection and alcoholic and non-alcoholic fatty liver disease. Hepatoma Res 2018;4:55. http://dx.doi.org/10.20517/2394-5079.2018.38

Received: 10 Apr 2018 First Decision: 8 Jul 2018 Revised: 15 Jul 2018 Accepted: 16 Jul 2018 Published: 20 Sep 2018

Science Editor: Guang-Wen Cao Copy Editor: Huan-Liang Wu Production Editor: Zhong-Yu Guo

\begin{abstract}
Hepatocellular carcinoma (HCC) is the main tumor of the liver and is the sixth most frequently diagnosed tumor in the world. It is the evolution of chronic hepatic injury secondary to different etiologies. Chronic hepatitis B virus and hepatitis $C$ virus infection, chronic alcoholic hepatitis, as well as non-alcoholic fatty liver disease are the most common causes behind the development of HCC. The introduction of effective prophylaxis and treatment against hepatitis $B$, the recent use of highly effective hepatitis $C$ treatments, as well as lifestyle changes observed in recent decades in the general population causing an increase in obesity and metabolic syndrome have led to significant epidemiological change in HCC in relation to the changed etiologic prevalence of liver injury. Increasing evidence was emerging, emphasizing how the development of HCC is a complex and multifactorial process. The knowledge of the molecular mechanisms involved is important for the understanding of the basic factors of the development of hepatocarcinogenesis and of possible therapeutic approaches. Several pathogenic mechanisms and clinical expression of HCC occur in relation to the different etiologies of the underlying liver disease. The different clinical behavior of HCC often makes diagnosis difficult at an early stage, that is necessary for an effective therapeutic approach. This review analyzes the possible different pathogenic mechanisms involved in the development of HCC and emphasizes the different epidemiological and clinical aspects of HCC observed in the most common forms of liver diseases of viral and non-viral origin.
\end{abstract}

Keywords: Hepatocellular carcinoma, hepatitis C virus, hepatitis B virus, alcohol hepatitis, non-alcoholic fatty liver disease

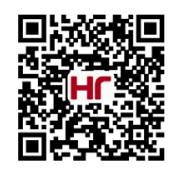




\section{INTRODUCTION}

Liver cancer is the fourth leading cause of cancer-related death in the world, with about 810,000 deaths annually $^{[1]}$. It has a high incidence rate and is the fifth most commonly diagnosed cancer in males and the ninth in females ${ }^{[2]}$. In addition, unlike other more common neoplasms that have a downward trend in incidence, the rate of incidence of liver cancer appears to be increasing ${ }^{[3]}$. Hepatocellular carcinoma (HCC) is the most common liver cancer histotype, accounting for $80 \%$ of the liver cancers ${ }^{[4]}$.

At present the main causes of $\mathrm{HCC}$ are viral infections such as hepatitis B virus (HBV) and hepatitis $\mathrm{C}$ virus (HCV) and alcohol abuse, but the obesity and the metabolic syndrome epidemic that is occurring in Western countries is leading to a significant increase in HCC secondary to non-alcoholic fatty liver disease (NAFLD) ${ }^{[1,5]}$. Chronic HBV infection is associated with about $33 \%$ of total deaths observed for HCC, while $30 \%$ is associated with alcohol abuse, $21 \%$ with chronic HCV infection and $16 \%$ with the remaining etiologies, including the everincreasing metabolic etiology ${ }^{[1]}$. In fact, widespread lifestyle changes and the pandemic of the metabolic syndrome are causing a significant increase of about $9 \%$ per year in the incidence rates of NAFLD-associated HCC. Looking to the future, particularly in industrialized countries, this last condition could become the main factor of HCC causing an important epoch-making change between metabolic and viral forms ${ }^{[6]}$.

The pathogenic mechanisms underlying the development of HCC, as well as the epidemiology, the clinics and the underlying diseases from each etiology are extremely dissimilar and explain the heterogeneous clinical impact of HCC. The different clinical behavior of HCC often makes diagnosis difficult at an early stage that is necessary for an effective therapeutic approach. Increasing evidence is emerging, emphasizing how the development of HCC is a complex and multifactorial process. The comprehension of the molecular mechanisms involved is important for the understanding of the basic factors of the development of hepatocarcinogenesis and of possible therapeutic approaches.

This review aims to define an updated clinical picture of HCC, its epidemiological changes and, above all, to highlight the differences in the pathogenic mechanisms related to each single etiology associated with HCC. Table 1 summarizes the main characteristics of HCC in relation to the different etiological association.

\section{The common denominator in the pathogenesis of HCC}

Regardless of etiology, any chronic hepatitis can alter the balance of the immune system causing a low-grade chronic inflammation that leads to the creation of reactive oxygen species (ROS), as well as the induction of cell proliferation and the onset and progression of liver fibrosis. A high turnover of hepatocytes exposes the patient to a higher rate of genetic alteration, such as point mutations, chromosomal abnormalities or epigenetic alterations, whose accumulation represents the first phase of hepatocarginogenesis. In addition, there are specific risk factors of the host such as diabetes mellitus and the male sex, and factors related to the etiological agent that increase the oncogenic potential of the inflammatory liver disease, thus causing the development of HCC, either in the presence or absence of significant hepatic fibrosis ${ }^{[7]}$.

Irrespective of etiology, cirrhosis of the liver is an already pre-malignant condition that promotes the development of genetic aberrations and cellular transformations. In fact, the chronic hepatic inflammatory state and the accelerate hepatocyte turnover observed in cirrhosis promote the accumulation of genic mutations. The subsequent uncontrolled proliferation and the high rate of genetic errors will lead to the development of HCC.

\section{HCC and HBV chronic infection}

Clinical and epidemiological factors affecting development of HBV-related HCC

Currently, chronic HBV infection is responsible for about half of all observed HCC cases ${ }^{[8-11]}$. It has been estimated that HCC occurs 10-25 times more frequently in patients with positivity for HBV than uninfected 
Table 1. Main features of HCC in relation to different etiologies

\begin{tabular}{|c|c|c|c|c|}
\hline HCC & & Related to & & \\
\hline Features & HBV & HCV & ALCOHOL & NAFLD \\
\hline Annual Incidence & Non-Cirrhotic: $0.3 \%-0.6 \%$ & $3 \%-7 \%$ & $1.2 \%-5 \%$ & NAFLD: $0.044 \%$ \\
\hline & Cirrhotic: $2.2 \%-3.7 \%$ & Increasing & Stable & NASH: 0.529\% \\
\hline & Low Increasing & & & Increasing \\
\hline Gender Prevalent & Male & Male & Female & Indifferent \\
\hline $\begin{array}{l}\text { Onset stage of liver } \\
\text { disease }\end{array}$ & Chronic hepatitis Cirrhosis & Cirrhosis & Cirrhosis & $\begin{array}{l}\text { Chronic Hepatitis } \\
\text { Cirrhosis }\end{array}$ \\
\hline Carcinogenic factors & Viral factors & Viral factors (Genotype-related) & Direct (dose-related) & Inflammation \\
\hline & Inflammation & Inflammation & Inflammation & Oxidative stress \\
\hline & Oxidative stress & Oxidative stress & Oxidative stress & Lipid peroxidation \\
\hline & Cirrhosis & Cirrhosis & Endotoxinemia & Mitochondrial damage \\
\hline & Immunologic & & Low Vitamin A levels & Endotoxinemia \\
\hline & $\begin{array}{l}\text { Genetic polymorphisms (DCL1, } \\
\text { TGF- } 31 \text {, STAT4, TPTE2, CTL-4, } \\
\text { MDM2, among Asians) }\end{array}$ & & Cirrhosis & Cirrhosis \\
\hline Co-factors & Viral co-infection (HIV, HDV, HCV) & & Genotoxicity & \\
\hline & Diabetes & Viral co-infection (HBV, HIV) & Diabetes & Diabetes \\
\hline & Alcohol & Diabetes & Obesity & Metabolic syndrome \\
\hline & Tobacco & Metabolic syndrome & $\begin{array}{l}\text { Genetic polymorphisms } \\
\text { (PNLA3, TM6SF2) }\end{array}$ & $\begin{array}{l}\text { Leptin/adiponectin } \\
\text { imbalance }\end{array}$ \\
\hline & & Obesity & & $\begin{array}{l}\text { Genetic polymorphism } \\
\text { (PNLA3) }\end{array}$ \\
\hline & & Alcohol & & \\
\hline & & Iron overload & & \\
\hline Related-death of total & $33 \%$ & $21 \%$ & $30 \%$ & $16 \%$ \\
\hline $\begin{array}{l}\text { Effect of anti-viral } \\
\text { treatment on incidence }\end{array}$ & Reduced & Reduced & & \\
\hline
\end{tabular}

individuals ${ }^{[12]}$. HBV-related HCC is predominantly observed among males (203,000 new cases in 2015 versus 70,000 in females), with a male-to-female ratio of about 3 to 1 and is also responsible for one-third of HCCrelated deaths ${ }^{[1]}$. In addition to epidemiological factors, the significant disparity in incidence between the two sexes is also determined by the different hormonal pathways. Androgens stimulate virus replication and transcription in males causing a higher viral load which is associated with an increased risk of occurrence of $\mathrm{HCC}^{[13]}$. In fact, high HBV-DNA serum levels have been reported to be associated with a nonlinear doseresponse to a higher incidence and recurrence of $\mathrm{HCC}^{[14]}$. Furthermore, it has been reported that estrogens appear to act as protectors towards the development of $\mathrm{HCC}^{[15]}$.

HBV-related HCC shows a tendency to occur at all stages of the natural history of chronic HBV hepatitis and not only in cirrhosis as in most cases seen during chronic HCV and alcoholic hepatitis. Accordingly, up to a third of patients develop HCC on a non-cirrhotic liver ${ }^{[12]}$.

An additional factor associated with an increased risk of developing HCC is the duration of the disease ${ }^{[16]}$. The chronic inflammatory state and hepatic oxidative stress induced by chronic HBV infection accelerate cell senescence processes. The expression of aging processes is expressed at the genomic level in the form of shortening of telomeres, whose length is inversely proportional to the degree of fibrosis and reaches the lowest values in $\mathrm{HCC}^{[17]}$. Although cellular senescence is a protective mechanism itself, since it limits proliferation and reduces the risk of carcinogenic transformation, it has been shown that telomerase activity persists at high levels in $80 \%-90 \%$ of HCC cases thus emphasizing the development of escape mechanisms from the protective phenomena of cellular aging ${ }^{[12,18]}$.

It has been shown that some co-factors associated with chronic HBV infection such as diabetes mellitus, alcohol consumption or tobacco use, as well as exposure to carcinogens (e.g., aflatoxin) may act in synergy with the virus in determining an early onset and a more rapid progression of $\mathrm{HCC}^{[19,20]}$. In particular, the 
risk of developing HCC has been reported to be 6-, 5- and 4-fold higher in the case of concomitant use of alcohol, tobacco and in the presence of obesity, respectively ${ }^{[21]}$.

The presence of HBV coinfection with HIV or HDV or HCV causes a more rapid progression of liver disease and a significant higher occurrence of HCC even in the early stages of the disease ${ }^{[22,23]}$.

HBV genotype appears to significantly influence the appearance of HCC. In particular, it has been reported that HBV genotype C, which has a high prevalence in Southeast Asia, is associated with a higher risk of HCC compared to other genotypes ${ }^{[24,25]}$. It has been shown that HBV genotype $\mathrm{C}$ most frequently causes double helix breaks in the host genome, induces a greater stress of the endoplasmic reticulum through the accumulation of ROS and causes a greater number of chromosomal rearrangements that can promote carcinogenesis as better described below ${ }^{[26]}$.

As mentioned above, high viral loads, as well as a seropositive status of HBe antigen (HBeAg) are associated with a higher risk of developing $\mathrm{HCC}^{[14]}$. It has been reported that $\mathrm{HBeAg}$ seropositive patients has a relative risk of HCC of 60.2 compared to 9.6 of those seronegative ${ }^{[27]}$. It has also been shown that high levels of HBVDNA are closely linked to a high probability of developing $\mathrm{HCC}^{[28]}$.

A genetic predisposition to the development of HCC during HBV infection has been reported among SouthAsians. Single nucleotide polymorphisms (SNPs) at the level of several genes, e.g. DCL1, TGF- $\beta 1$, STAT4, TPTE2, CTL-4, MDM2 have been associated with the development of $\mathrm{HCC}^{[12,29-33]}$. It is unknown, however, if these data may be extended to other ethnicities.

\section{Pathogenic mechanisms of HBV-related HCC}

HBV can cause the onset of HCC through direct and indirect mechanisms. The direct carcinogenic effect of HBV derives from its ability to integrate its own genome into that of the host, altering chromosomal stability and triggering various oncogenic mechanisms. In the early stages of the natural history of infection, HBVDNA is converted into a covalently closed circular DNA form (cccDNA $)^{[34]}$ that allows the virus to persist in the infected cell nucleus and acts as a reserve for viral genome replication ${ }^{[12]}$. Although viral integration is more likely to occur randomly, whenever it occurs at the level of specific sites in the host genome, which are either close to the genes involved in cell cycle regulation and proliferation or those involved in cell survival mechanisms, can allow the clonal expansion of cells $^{[35,36]}$. This mechanism is also responsible for the constant expression of viral oncogenic proteins such as $\mathrm{HBx}$ or preS/S polypeptides, which over time may lead to alterations in the control of cell transcription and proliferation ${ }^{[12]}$. The fact that such integration is more commonly seen in cancer tissue than in adjacent liver tissue ( $86.4 \%$ and $30.7 \%$, respectively) seems to be an evidence of the central role played by viral genome integration in the development of $\mathrm{HCC}^{[37]}$. In this context, the transcription of a chimeric gene (viral/human) called HBxLINE1 has recently been identified and has been found in about a quarter of patients with HCC and associated with a worse prognosis ${ }^{[38]}$.

In addition to the integration mechanisms of the viral genome, specific mutations in the $X$ regions, pre-core, core-promoter and pre-S may increase the risk of developing $\mathrm{HCC}^{[39,40]}$. Among the most frequent mutations at the nuclear promoter level, the double mutation A1762T/G1764A is closely related to the probability of developing HCC. The presence of this mutation may represent a potentially risk-predictive biomarker for $\mathrm{HCC}$ as its presence may be evident many years before the development of $\mathrm{HCC}^{[41]}$. Several other potentially oncogenic mutations have been identified in the pre-S region. The combination of pre-S C1653T, C1653T $+T 1753 \mathrm{~V}$ mutations and the aforementioned A1762T/G1764A have a specificity greater than $80 \%$ in the prediction of HCC development ${ }^{[42]}$. HBV-infected patients with mutations in the pre-S region have a 3.8fold higher risk of developing HCC than non-mutated virus infection. These mutations are present in about $60 \%$ of cases of HCC and may alter the protein expression of the viral envelope. The accumulation of surface 
proteins mutated at the endoplasmic reticulum may be able to induce the formation of ROS, with consequent oxidative stress to the host DNA and induction of the hepatocyte transformation ${ }^{[12,43-45]}$. Mutations in the $S$ region can also contribute to the development of HCC. In this regard, it has recently been shown that a nonsense mutation at position 172 or 182 of viral genome can contribute significantly to the progression of liver disease, and in particular the sW182 mutation was found to be related to the development of HCC ${ }^{[46]}$.

In addition to the structural proteins, the viral genome also codes for HBx proteins that is involved in the transcription mechanisms of cccDNA and viral replication and seems closely related to the oncogenicity of $\mathrm{HBV}^{[35,47,48]}$. HBx appears to be able to cause chromosomal instability affecting the mitotic checkpoints, cell proliferation through stimulation of CREB genes, inhibition of apoptosis through interaction with p53, promotion of neoangiogenesis through stimulation of vascular endothelial growth factor and angiopoietin 2 (ANG2) and induction of cell migration phenomena inducing the matrix metalloproteinase 3 and 9 expression $^{[49,50]}$. Accordingly, HBx appears to be a crucial point of the oncogenic power of the virus, as well as in promoting invasiveness and the ability to metastasize of $\mathrm{HCC}^{[35]}$. $\mathrm{HBx}$, among other things, inhibits senescence mechanisms through inhibition of p53 and inactivation of the suppression factors of cancer ${ }^{[51]}$.

A great research interest is growing on the effects of viral protein expression such as wild type and $\mathrm{HBx}$ mutant, envelope and core proteins on different transcription and signaling pathways such as Wnt/ $\beta$-catenin, TGF- $\beta$, NFkB, Raf/MAPK, P53 and ROS involved in the pathogenesis of HCC related to HBV. The betacatenin pathway regulates multiple cellular processes and plays an important role in hepatocarcinogenesis and in progression from chronic inflammation to $\mathrm{HCC}^{[52]}$. Mutations in the CTNNB1 gene (catenin beta 1) may activate the Wnt/ $\beta$-catenin pathway and lead to the accumulation of $\beta$-catenin in HCC. The Wnt $/ \hat{I}^{2}$ catenin pathway is a potential promising target for future molecular HCC therapies ${ }^{[53]}$.

\section{Effect of Immune-tolerance phase of HBV infection and occult HBV on development of HCC}

The immune tolerance phase of HBV infection is characterized by a high level of viral replication in the absence of significant cytolytic activity. These patients have been defined to be at low risk of disease progression, so, at present, there is no indication for antiviral treatment ${ }^{[54,55]}$. However, recent studies have questioned this principle by demonstrating high levels of chromosomal integration and clonal expansion of the viral genome and hepatocytes, emphasizing that carcinogenesis may also occur at this stage and in the absence of cytolytic activity ${ }^{[56]}$. In addition, a prospective study showed that the estimated cumulative incidence of HCC over a 10-year follow-up period is significantly higher in the immune tolerant group than the active immune group $(12.7 \% \text { vs. } 6.1 \% \text {, respectively })^{[57]}$. Furthermore, data from a recent study have demonstrated the benefits in terms of clinical outcomes such as the development of cirrhosis and HCC of antiviral treatment even during the immune tolerance phase ${ }^{[58]}$. Therefore, it was hypothesized that HBV positive patients not treated in the immune tolerance phase may be at a higher long-term risk of $\mathrm{HCC}^{[57]}$. On this basis it was suggested that the immune tolerance phase should not be more considered a "benign" condition and that the levels of HBV-DNA rather than alanine aminotransferase (ALT) values should be considered when estimating the risk of occurrence of $\mathrm{HCC}^{[58,59]}$. Further study and consensus will be needed to define this important aspect.

A special mention must be made for the so-called occult HBV infection (OBI), a condition in which HBVDNA is detectable in the liver and possibly in the serum at low levels in the absence of HBsAg in the serum. Several studies point out that the OBI can be a hazardous condition for the development of HCC $^{[60,6]}$. In these patients many of the above-described oncogenic mechanisms associated with HBV remain active. Recent evidence has shown that an OBI condition was present in $75 \%$ of HBsAg negative HCC cases, underlining the possible OBI role in HCC genesis ${ }^{[62]}$. Furthermore, a condition of occult infection that increases the risk of developing HCC seems to persist longer in the neoplastic tissue itself than in adjacent tissue ${ }^{[61,63]}$. It has also been shown that the risk of developing HCC is significantly higher in patients with 
HCV-related cirrhosis and concomitant OBI carrier status than in negative OBI patients ${ }^{[64]}$. Therefore, regardless of the etiology, in patients with chronic hepatitis the presence of OBI may represent a significant co-factor for the development of HCC.

\section{Effect of HBV treatment on development of HCC}

It is well known that the long-term suppression of viral replication through the nucleos(t)ide analogues reduces but does not eliminate the risk of HCC. Several large patient case studies have shown that HCC incidence rates have significantly decreased in patients undergoing treatment ${ }^{[65,66]}$. It has recently been confirmed that the reduced incidence of HCC in patients receiving antiviral treatment is independent of age, sex, HBeAg status, cytolysis level and the presence of cirrhosis ${ }^{[67]}$. Treatment does not appear to have a significant clinical impact on patients with low levels of viremia $(\mathrm{HBV}-\mathrm{DNA}<2000 \mathrm{IU} / \mathrm{mL})^{[67]}$. A large retrospective study of non-cirrhotic positive HBV patients showed that the incidence of HCC is significantly lower in patients receiving antiviral therapy regardless of the levels of $\mathrm{ALT}^{[68]}$. In addition, the required number of patients to be treated (NNT) to prevent 1 case of HCC 10 years after initiation of treatment was found to be similar both in the group of patients with ALT $<2$ ULN $(N N T=14)$ and in those with ALT $\geq 2$ ULN $(\mathrm{NNT}=15)^{[68]}$. These data appear to confirm that hyper-ALT should not be considered a necessary requirement for antiviral treatment in patients with HBV-DNA $>2000 \mathrm{IU} / \mathrm{mL}^{[69]}$.

\section{HCC and HCV chronic infection}

Clinical and epidemiological factors affecting development of HCV-related HCC

Chronic HCV infection is the third leading cause of HCC and accounts for about one-third of total incidence rates and one-fifth of HCC-related deaths ${ }^{[1]}$. In recent years, the incidence of HCV-related HCC has undergone the greatest increase compared to that associated with other etiologies ${ }^{[1]}$. The risk of developing HCC in the course of chronic HCV infection increases in proportion to the degree of hepatic fibrosis. In fact, most cases of HCV-related HCC occur during an established cirrhosis, suggesting that cirrhosis-mediated carcinogenesis may play a primary role in the development of $\mathrm{HCC}^{[70]}$. In patients with $\mathrm{HCV}$-associated cirrhosis it is estimated that the annual incidence rate of HCC is between $3 \%$ and $7 \%{ }^{[1,72]}$. The incidence of HCC is significantly higher among elderly patients ( $>60$ years) perhaps also due to the fact that the progression of fibrosis is related to the duration of the disease ${ }^{[73,74]}$. Compared to HBV infection or NAFLD, HCC related to HCV infection shows a tendency to appear in a more advanced phase of liver disease $^{[75]}$. In addition to cirrhosis, other factors such as diabetes mellitus, metabolic syndrome, fatty liver disease and obesity are associated with a higher risk of developing $\mathrm{HCC}^{[76-78]}$. The presence of HBV or HIV coinfection, alcohol abuse or iron overload are additional risk factors for hepatocarcinogenesis in HCVinduced cirrhosis ${ }^{[9,22,79]}$.

The role played by serum HCV-RNA levels in the development of HCC is controversial ${ }^{[80-82]}$. Lee et al ${ }^{[80]}$ in a large series reported that elevated serum HCV RNA levels were associated with a significant increase in the incidence of HCC. Furthermore, they demonstrated that the presence of elevated levels of hepatic cytolysis and HCV genotype $1(12.6 \%$ vs. $4.5 \%$ for non-genotype 1$)$ were associated with a higher HCC rate ${ }^{[80]}$. Other studies have confirmed the oncogenic potential of the HCV genotype $1^{[74,83]}$. A meta-analysis of 57 papers showed that patients with HCV genotype $1 \mathrm{~b}$ have twice the risk of developing HCC compared to patients with non-1 genotype ${ }^{[83]}$. Therefore, in patients with HCV infection the presence of high viremia, high levels of ALT and genotype 1 appear to be risk factors for HCC.

\section{Pathogenic mechanisms of HCV-related HCC}

$\mathrm{HCV}$ is unable to integrate its genome into host cells and requires a constant replication process to maintain chronic infection ${ }^{[84]}$. Therefore, its oncogenic potential appears to be mostly indirect and mediated by the development of significant hepatic fibrosis. HCV infection causes a chronic inflammatory state, induces hepatocyte necrosis, as well as collagen production and accumulation, which will eventually lead to an 
alteration of the structure of the hepatic parenchyma. The increase in hepatocyte turnover due to the continuous processes of cell death and regeneration, as well as the progression of fibrosis, lead to a high probability of genetic alterations, whose accumulation leads to the formation and proliferation of cell clones that favour the development of $\mathrm{HCC}^{[85]}$. Furthermore, apoptosis of hepatocytes can amplify the fibrogenic signal, thus stimulating the activation of stellate cells and causing the progression of hepatic fibrosis towards cirrhosis which is a pre-malignant condition ${ }^{[86]}$. HCV infection is also able to modify the intracellular signalling pathways of transforming growth factor beta (TGF- $\beta$ ) signalling, thus accelerating the progression of liver injury and increasing the risk of $\mathrm{HCC}^{[87]}$.

Although the pathogenesis of HCV-related HCC is mostly due to the development of cirrhosis and cell regeneration mechanisms, different alterations in gene expression and signal transduction pathways involved in cell proliferation and in the neoplastic transformation of hepatocytes have been described in chronic HCV infection ${ }^{[8]}$. In this regard, there are various demonstrations, mostly obtained on animal models, which suggest that different viral proteins may play a direct role in hepatocarcinogenesis ${ }^{[85,89-92]}$. The NS3 nonstructural protein is a serine protease that appears to be involved in the neoplastic transformation process by inducing the acquisition by the hepatocyte clones of a proliferative condition, as well as the escape from the host cell surveillance mechanisms ${ }^{[89]}$. In combination with the NS4A factor, it interacts with the ATM kinase and alters DNA cell repair mechanisms ${ }^{[93]}$. Similarly, the NS5A phosphoprotein appears to be able to alter the cell growth mechanisms and the physiological replication cycle of the host cell through interaction with the $\mathrm{CDK}_{1 / 2}$-cyclin kinase-dependent complex ${ }^{[90]}$. The HCV core protein and the E2 envelope protein have been shown to stimulate cell growth and heteroplastic degeneration ${ }^{[91,92]}$. The HCV core protein in particular seems to play a key role in the pathogenesis of HCC. Its oncogenic potential appears to be considerably high, as it causes oxidative stress on one side and alters the intracellular signalling cascade of the protein kinase on the other, resulting in a dysregulation of cell growth control ${ }^{[85]}$. In particular, the HCV core-protein is able to provoke an overproduction of ROS by increasing the lipid peroxidation and a mitochondrial dysfunction through the rearrangement of the lipoprotein double layer of the mitochondrial membrane ${ }^{[94,95]}$. The oxidative stress induced by the HCV core-protein leads to damages in the genome of the host cell with accumulation of genetic aberrations that predispose the evolution towards cancer ${ }^{[85,95,96]}$. Furthermore, the presence of insulin resistance and hepatic steatosis, which are associated with a high frequency to HCV infection, exacerbates the production of $\operatorname{ROS}^{[95]}$. In addition, the HCV core-protein is able to inhibit DNA repair mechanisms damaged by oxidative stress and alter various intracellular antioxidant systems ${ }^{[95,97]}$. At the same time, this protein is able to directly alter gene expression and intracellular regulation mechanisms. In this regard, a greater expression of tumor necrosis factor- $\alpha$ (TNF- $\alpha$ ) and interleukin-1 $\beta$ (IL-1 $\beta$ ) was observed, together with an higher activity of the relative downstream effectors c-Jun N-terminal kinase and activator protein-1, and a stimulation in the mitogen-activated protein kinase (MAPK) cascade ${ }^{[98,99]}$. HCV core-protein is also capable of inhibiting the tumor suppression genes RB1, TP53 and TP73 as well as cellcycle modulators such as $\mathrm{CDKN}_{1} \mathrm{~A}^{[98,100]}$. Cytokinesis overexpression and gene expression alterations may represent the mechanisms through which HCV core-proteins modulate the apoptotic signalling pathways and mechanisms of defence and proliferation of the hepatocytes. Histologically, transgenic mice carrying the core gene develop an early hepatic steatosis, similarly to what happens in men during chronic HCV infection. These mice show progressively the onset of hepatocellular adenomas characterised by the presence of numerous intracytoplasmic fat drops, which then evolve towards the formation of HCC more or less rich in lipid drops, depending on the stage of differentiation ${ }^{[101]}$. These data highlight the key role played by HCV core-protein in the process of carcinogenesis.

$\mathrm{HCV}$ is able to cause alterations in the glucose and lipid metabolism, another important factor in the development of $\mathrm{HCC}^{[85]}$. HCV, in fact, stimulates the activation of insulin-like growth factor (IGF), a cell growth regulator, through the induction of proliferative and anti-apoptotic mechanisms ${ }^{[102]}$. Through the degradation of insulin receptor substrate 1 and 2 (IRS-1 and IRS-2) ${ }^{[103]}$, the virus is also able to interfere with 
insulin signalling and induce insulin-resistance, which in turn is responsible for the activation of hepatic stellate cells and subsequent fibrosis ${ }^{[104,105]}$. The presence of insulin resistance or diabetes mellitus represent independent risk factors for the progression of the liver disease and the development of HCC in patients with chronic HCV infection ${ }^{[106]}$. Some evidence suggests that somatic mutations of the leptin receptor (LEPR) gene may increase the susceptibility to hepatocyte cancer transformation ${ }^{[107]}$.

Finally, virus-induced immune alterations can also help create an ideal environment for HCC development. The HCV, in fact, is able to inhibit the production of interferon type 1 and to alter the immune response of both $\mathrm{T}$ cells $\mathrm{CD} 8+$ and natural killer ${ }^{[105,108]}$. In combination with the aforementioned cytokine alterations and oxidative stress, these immune alterations contribute to the persistence of chronic inflammatory hepatic disease, which provides fertile soil for malignant degeneration.

\section{Effect of treatment on development of HCV-related HCC}

The recent introduction of direct-action antivirals (DAAs) for the treatment of HCV infection that causes a sustained virologic response (SVR) in more than $95 \%$ of cases appears to induce a significant decrease in HCC cases associated with this infection. As already demonstrated for interferon-based therapeutic regimens ${ }^{[109,110]}$, several studies seem to demonstrate that achieving SVR using DAAs reduces the risk of HCC $^{[111]}$. The incidence rate of HCC in cirrhotic patients with SVR may decrease up to $1 \%$ per year, although a lower rate of reduction is observed in patients with concomitant metabolic syndrome. However, because the risk of HCC in patients with cirrhosis persists even after HCV elimination, a reasonable time frame will be required before significant epidemiological changes can be observed ${ }^{[109]}$. Although it is quite clear that the achievement of SVR reduces the long-term risk of HCC, the possible role of DAAs in increasing the risk of HCC de novo and recurrence of HCC successfully treated is still a matter of debate ${ }^{[112]}$. In a meta-analysis of 26 studies including 11,523 patients ${ }^{[113]}$ it was found that there were no significant differences in incidence rates of de novo HCC between treatment regimens based on DAAs and IFN. Ioannou et al ${ }^{[114]}$ identified a $71 \%$ HCC risk reduction after achieving SVR through DAAs on a cohort of approximately 62,000 patients and confirming that there are no substantial differences in the HCC rate between patients treated with DAA and those treated with IFN. Kanwal et al. ${ }^{[115]}$ show that achieving SVR in patients treated with DAA is associated with a $76 \%$ reduction in the risk of HCC.

For what concerns the impact of DAAs on the recurrence of HCC previously treated with curative intent, the data available are still controversial and further studies may be necessary for a correct evaluation of the impact of DAAs therapeutic regimens on HCC recurrence risk.

\section{$\mathrm{HCC}$ and alcohol abuse}

\section{Clinical and epidemiological factors affecting development of HCC secondary to alcohol abuse}

Consumption of alcohol is the second leading cause of HCC worldwide, as it is responsible for around a third of cases $^{[1]}$. Europe and Latin America are the areas with the highest incidence rates of HCC secondary to alcohol abuse, accounting for about half of the total. It has been estimated that chronic alcohol consumption is associated with an approximately 2 -fold increase in the odds ratio for the development of HCC, but this risk increases up to 5-7 times if consumption exceeds $80 \mathrm{~g} /$ day for a time period of more than 10 years, thus underlining the close dose/risk correlation ${ }^{[116,117]}$. Although there is no absolute "threshold" dose that can be applied as a parameter to all people, as the risk of alcohol-related damage is individual, an average chronic consumption of $\geq 2 \mathrm{drink} /$ day in females and $\geq 3 \mathrm{drink} /$ day in males for longer than a 10-year time span is associated to the onset of alcoholic liver disease (ALD), which encompasses a wide spectrum of clinical pictures ranging from steatosis to steatohepatitis to the development of liver cirrhosis. From the time when cirrhosis is established, the risk of occurrence of HCC is $1 \%-2.5 \%$ per year ${ }^{[118,119]}$. Compared to other etiologies, the risk of neoplastic transformation appears to be lower among ALD patients. In fact, a recent observational study showed that the cumulative incidence rates of HCC after 10 years of observation were lower in ALD cases (8.4\%) than in cases of chronic HCV infection (22\%) and NAFLD (23,7\%), with an annual incidence 
rate of $1.1 \%, 2.9 \%$ and $3.1 \%$ respectively ${ }^{[119]}$. In this regard, however, the data in the literature seem to be conflicting.

The amount and duration of the alcohol consumption are directly related to the stage of the liver disease and the risk of $\mathrm{HCC}^{[116]}$. In particular, the cumulative lifetime amount of alcohol assumed acts as a major determinant of oncologic risk ${ }^{[120]}$. A $\geq 3$ drink/day consumption is strongly associated with the incidence of HCC and liver-related death ${ }^{[121]}$. Furthermore, alcohol consumption is also closely related to the more rapid increase in cancer growth once it has developed ${ }^{[122]}$. This highlights the importance of the dose-response relation between alcohol consumption and HCC.

The female gender has an approximately 5 -fold higher risk of developing liver cirrhosis and/or HCC for lower doses of alcohol than males ${ }^{[121]}$. In addition, females appear to show a faster progression of the damage towards cirrhosis in comparison with males ${ }^{[123]}$.

A meta-analysis ${ }^{[124]}$ evaluated the occurrence of HCC after cessation of alcohol use. An annual reduction of $6 \%-7 \%$ of the risk of developing HCC after cessation of alcohol consumption was estimated and an average period of 23 years because the risk is comparable to that of an ever ethylist.

Although the cumulative amount of alcohol during the lifetime is the main predictor of the risk of HCC, not all alcohol users are destined to develop cirrhosis and/or HCC. Indeed, a number of both genetic and clinical cofactors are also implicated in modulating the risk of ALD evolution to $\mathrm{HCC}^{[125]}$. Several SNPs have been reported to increase the risk of HCC, in particular those able to interfere with the metabolism of ethanol and lipids (PNPLA3, TM6SF2), as well as hepatic iron accumulation ${ }^{[126-128]}$.

Different co-morbidities can modulate cancer risk. Obesity is an important co-factor in the development of alcohol-induced HCC ${ }^{[129,130]}$. The risk of developing HCC is three times higher among alcohol users with a $\mathrm{BMI} \geq 30 \mathrm{~kg} / \mathrm{m}^{2}$ compared to those not taking alcohol and with a lower BMI ${ }^{[131]}$. This synergy is also recognized to exist between alcohol and other co-factors of liver injury ${ }^{[132]}$. The coexistence of diabetes mellitus and chronic alcohol consumption leads to a significant increase in the risk of developing $\mathrm{HCC}^{[129,133,134]}$.

A study of patients with alcoholic cirrhosis showed that the incidence of HCC among patients with and without diabetes mellitus was $32.7 \%$ and $3.2 \%$ after 5 years, $32.7 \%$ and $20.2 \%$ at 10 years, $66.3 \%$ and $20.2 \%$ at 15 years, respectively ${ }^{[135]}$. It has been reported that the risk of HCC among patients with diabetes mellitus who consume more than 4 drinks/day has increased by 4.2 times $^{[136]}$.

The high consumption of alcohol in cirrhotic patients with concomitant HBV infection increases the risk of HCC by about $10 \%$ per year, apart from the progression of its onset at an earlier age ${ }^{[132,137,138]}$. Similarly, data are reported for OBI or previous HBV infection ${ }^{[139,140]}$. Several studies conducted on alcoholic subjects show the synergistic effect with chronic HCV infection ${ }^{[141,142]}$ or hemochromatosis ${ }^{[143]}$ on the incidence of HCC. Simultaneous exposure to alcohol and tobacco also appears to increase the risk of HCC $^{[129]}$.

\section{Pathogenic mechanisms of HCC secondary to alcohol abuse}

The presence of cirrhosis is the major mechanism related to the development of HCC. However, alcohol is able to directly induce carcinogenesis causing oxidative stress, inflammation and endotoxinemia.

Ethanol is first converted to acetaldehyde and then to acetate by alcohol-dehidrogenase (ADH) and acetaldehyde-dehidrogenase $(\mathrm{ALDH})$ respectively, within a process that increases the NADH/NAD ${ }^{+}$ ratio $^{[144]}$. This condition, in turn, causes a drastic change in the mitochondrial redox balance, which leads 
to an increase in the oxidation of fatty acids, as well as of lipogenesis, thus inducing the development of steatosis ${ }^{[145]}$. Ethanol is able to inhibit hepatocyte $\beta$-oxidation, increasing the synthesis and the uptake of fatty acids as well as promoting liver steatosis and inflammation ${ }^{[146,147]}$. Acetaldehyde, in addition to being toxic, is also highly oncogenic. The highest levels of ADH activity in tumor cells, when compared to ALDH, indicate that they have a high oxidation capacity of ethanol but a low ability to remove acetaldehyde ${ }^{[148]}$. Chronic alcohol consumption acts as an activator of cytochrome CYP2E1, which in turn increases the hepatic production of acetaldehyde. Its accumulation is responsible for the production of ROS that gives rise to oxidative stress induced by alcohol. The latter is responsible for mitochondrial damage, which in turn increases the production of ROS, thus creating a vicious circle that maximizes oxidative stress in the hepatocytes ${ }^{[149]}$. The accumulation of iron in the liver ${ }^{[150]}$ and the low oxygen tension of the tissue induced by alcohol are also responsible for the production of ROS. Furthermore, accumulation of intracytoplasmic lipid droplets in ethanol-induced steatosis (as well as in NAFLD) can make hepatocytes more susceptible to toxic or other insults ${ }^{[151]}$. It follows that the subsequent generation of ROS, in combination with the accumulation of damaged proteins and the increased susceptibility acquired by hepatocytes to damage of other nature, is able to induce lipid peroxidation, enzymatic inactivation and mutations of DNA, which can cause cell damage and inhibit apoptosis ${ }^{[149]}$. In particular, alterations in cellular DNA methylation processes (especially at levels of the oncosuppressor genes such as RASSF1A and/or DOK1) represent one of the most frequent genotoxic effects of chronic alcohol consumption ${ }^{[152]}$. All this causes serious abnormalities in the proliferation of hepatocytes, which may eventually lead to the development of HCC.

Alcohol induces alteration of the microbiota and may contribute to the development of liver injury and HCC. Damage to the tight junctions of the intestinal epithelium following the chronic abuse of ethanol increases the permeability of the intestinal barrier and promotes the migration of bacteria and endotoxins from the intestine to the portal system, thus fuelling the previously caused liver inflammatory status ${ }^{[153]}$. Bacterial endotoxin interacts with the toll-like receptors (TLR) present at the Kupffer's cells, stimulating the production of pro-inflammatory cytokines that contribute to the progression of alcohol-induced liver injury ${ }^{[153]}$. The alteration of TLR4 following the translocation of intestinal bacteria is able to induce carcinogenesis by interacting with cancer-initiating stem-like cells ${ }^{[154-156]}$. The TLR4/intestinal microbiota interaction through processes of cellular proliferation stimulation and apoptosis inhibition play a role in the progression of HCC but it is not required for the induction of $\mathrm{HCC}^{[156]}$.

As for other etiologies, alteration in the length of the chromosomal telomere occurs also in the course of ALD. It has been shown that the telomeres of individuals taking> 4 drinks/day are shorter than those of subjects who take $\leq 4$ drinks/day ${ }^{[157]}$ and that telomerase reactivation is closely related to the mechanisms of induction of hepatocarcinogenesis through uncontrolled hepatocyte replication ${ }^{[148,158]}$.

A further mechanism of induction of HCC secondary to ALD is represented by the impact of alcohol on the homeostasis of vitamin A, whose hepatic level decreases in chronic alcohol consumption ${ }^{[159]}$. Alcohol acts as a competitive inhibitor of vitamin A, inducer of its catabolism, through CYP2E1 and is a promoter of its mobilization from the liver to peripheral tissues ${ }^{[160]}$. Reduced levels of vitamin A in the liver can contribute to the development of HCC by altering the mechanisms of cell proliferation and apoptosis ${ }^{[149,161]}$.

From the above it is clear that ethanol abuse plays an important role as a promoter rather than an inducer of cancer development through a process in which oxidative stress is the basis of alcohol-induced cytotoxicity.

\section{HCC and NAFLD}

Clinical and epidemiological factors affecting development of NAFLD-related HCC

Due to the recent obesity and metabolic syndrome epidemic, NAFLD is currently the fastest growing chronic liver disease worldwide. The overage prevalence of NAFLD is currently estimated at $25 \%{ }^{[5]}$. It is 
characterized by the intrahepatic accumulation of triglycerides and includes a spectrum of diseases ranging from simple steatosis to steatohepatitis (NASH) and to cirrhosis of the liver. The annual incidence of HCC in patients with NAFLD is reported to be 0.44 in 1000 patients, while the annual incidence in patients who have already developed NASH is 5.29 cases in 1,000 patients $^{[5]}$. It has been estimated that NAFLD is responsible for about $14 \%$ of HCC cases in the United States, with an annual rate of increase of $9 \%{ }^{[6]}$.

A recent meta-analysis of cases of liver cancer diagnosed in the United States between 2004 and 2009 showed that the prevalence of HCC secondary to NAFLD is about $14 \%{ }^{[6]}$. The estimated annual cumulative incidence of HCC in cirrhosis by NAFLD is $2.6 \% \%^{[5,73,160]}$. A recent study of our group found an annual rate of incidence of $3.5 \%$ of HCC in patients with cirrhosis from NAFLD, this incidence is slightly lower than that observed in cirrhosis secondary to HCV $(4.5 \%)^{[75]}$. Similar annual incidence rates of HCC were also observed by Ascha et al. ${ }^{[162]}(2.6 \%$ and $4.0 \%$ in patients with metabolic cirrhosis and HCV-related cirrhosis, respectively).

However, as already mentioned, increasing evidence suggests that NAFLD may cause the development of HCC even in non-cirrhotic patients with mild or absent fibrosis ${ }^{[133,163-168]}$. There are conflicting data on the true prevalence of HCC on non-cirrhotic steatotic liver ${ }^{[169]}$. A recent review of data on 61 studies published between 1992 and 2011 shows that the risk of HCC in non-cirrhotic patients with NAFLD appears to be extremely $\operatorname{low}^{[166]}$. On the other hand, there are several studies that support the opposite hypothes is ${ }^{[163,164,167,168,170]}$. In a group of 31 patients with NAFLD and HCC, Paradis et al ${ }^{[164]}$ observed that, $65 \%$ of cases were in a F0-F2 fibrosis stage, whereas in the control group with liver disease of another etiology, only $26 \%$ of HCC were in the Fo-F2 fibrosis stage. Mittal et al. ${ }^{[167]}$, in a cohort of 107 patients with HCC and NAFLD, $34.6 \%$ of liver cancer cases occurred in the absence of cirrhosis. Piscaglia et al ${ }^{[168]}$ have recently observed a high incidence rate (70\%) of HCC in non-cirrhotic patients with NAFLD, although histology was only available for one third of patients.

The evaluation of further co-factors appears to be fundamental for the individual assessment of the risk of HCC. Obesity and diabetes mellitus in particular are by now well-known independent risk factors for HCC. Calle et al. ${ }^{[78]}$ have shown, in a large cohort of patients, how obesity increases the risk of HCC by 2-4 times. In comparison with individuals with normal weight, Larsson et al. ${ }^{[17]}$ estimated the risk of HCC in normal weight and obese subjects by establishing a relative risk of 1.17 and 1.89 , respectively.

It has been shown that the presence of diabetes mellitus increases the risk of HCC in patients with NAFLD $^{[19,172,173]}$. A recent study of 480 patients with NAFLD or ALD showed that the prevalence of HCC among diabetic patients was statistically higher compared to normoglycemic patients (8\% and 3\%, respectively) and the incidence rate of HCC during 3 years follow-up was almost three times higher (27\% and $10 \%$ respectively ${ }^{[172]}$. Davila et al ${ }^{[173]}$ confirm that the risk of HCC is three times greater in the presence of diabetes mellitus. Furthermore, diabetes mellitus and obesity can act in synergy. An Italian study has observed that the presence of one of the two factors leads to 3.5 odds ratio (OR) of HCC, while the OR increases to 11.8 in the presence of both, compared to normal weight and normo-glycemic subjects ${ }^{[174]}$. Therefore, an obese and diabetic patient with NAFLD is the most classic patient phenotype that shows a high probability of developing HCC, particularly when co-factors are associated with an existing hepatic damage. In fact, when obesity is accompanied by chronic alcohol consumption or by HCV or HBV infection, the risk of developing HCC shows a tendency to increase exponentially, thus observing the synergistic action of these co-factors of hepatic injury ${ }^{[130,175,176]}$.

The general clinical picture of HCC occurring in NAFLD shows peculiar characteristics. In this regard, Younossi et al. ${ }^{[6]}$ showed how the development of HCC on NAFLD involves an older average population with a higher prevalence of cardiovascular disease. Weinmann et al. ${ }^{[177]}$ confirm a high average age (67.6 years) of patients with HCC in NAFLD, a higher prevalence among males, a higher incidence of 
myocardial infarction and ischemic stroke, as well as a higher prevalence of obesity and diabetes mellitus. NAFLD-HCC patients show lower mean ALT levels and a higher platelet count than HCV-related HCC patients $^{[75,178]}$.

The onset of HCC in NAFLD is generally an early event in the natural history of liver disease ${ }^{[75,177]}$. In fact, the incidence of HCC on metabolic cirrhosis in a Child-Pugh A score appears to be 1.8 times higher than that observed in HCV-related cirrhosis ${ }^{[75]}$. In a recent Italian study the diagnosis of HCC was placed at an early stage (Child-Pugh A) in $82.3 \%$ of patients with NAFLD, compared to $68.1 \%$ of patients with chronic HCV infection ${ }^{[168]}$. The model for end-stage liver disease scoring (MELD) is also significantly lower for HCC in NAFLD than in other etiologies ${ }^{[177]}$.

Contrary to the stage of cirrhosis of the liver, the stage of the diagnosis of the neoplasia is generally more advanced for the HCC related to the NAFLD than for other etiologies. Compared to patients with HCV infection, HCC in patients with NAFLD often presents greater dimensions at diagnosis and more frequently shows infiltration ( $21 \%$ in patients with NAFLD versus $4 \%$ in patients with HCV) or multifocal lesions ${ }^{[168,170,178]}$.

The diagnosis in the advanced stage of neoplasia is not due only to the pathogenic mechanisms and epidemiological factors mentioned above but is mainly due to the lower attention to follow-up and screening of NAFLD ${ }^{[179,180]}$. The diagnosis of HCC in patients with NAFLD is often incidental, outside the surveillance protocols and in any case late, as it is dependent on the appearance of symptoms ${ }^{[168,178]}$. Patients with NAFLD seem to have the highest rate of cirrhosis undiagnosed before evidence of HCC compared to other etiologies, resulting in a decrease in attention to ultrasound surveillance and subsequent delay in the diagnosis of HCC. Furthermore, as another condition of difficulty in early diagnosis, it must be emphasized that the sensitivity of ultrasound in detecting small cancer is low in patients with NAFLD ${ }^{[181,182]}$.

Along with a generally more advanced stage of cancer diagnosis, there are additional reasons why the prognosis of patients with HCC related to NAFLD appears to be worse than patients with HCC of different etiology ${ }^{[6,177]}$. In fact, the prognosis is negatively affected by a greater number of comorbidities, especially cardiovascular, to which this subgroup of patients is exposed. The highest rate of co-morbidities such as obesity, the highest mean age of patients with NAFLD and often delayed diagnosis lead to fewer liver transplants for these patients ${ }^{[6,168,170,177]}$. Finally, the advanced stage of the disease is often a limitation for the applicability of radical treatments (resection or ablation) in favour of purely palliative interventions (chemoembolization or pharmacological therapy). In fact, liver resection and transplantation are only practiced in $17.8 \%$ and $4.4 \%$ of cases, respectively ${ }^{[177]}$. As a result, the death rate in HCC secondary to NAFLD (61\% of patients die within one year of diagnosis) is higher than in HCC secondary to viral hepatitis (50\% of deaths within one year of diagnosis), with a shorter average life expectancy of 5 months ${ }^{[6]}$. Piscaglia et al. ${ }^{[168]}$ observed an average survival of 25.5 months from diagnosis in patients with NAFLD-HCC, versus an average 33.7 months of patients with HCV-related HCC. However, when the patient is eligible for curative treatment, survival does not appear to vary between HCC related to NAFLD and other etiologies ${ }^{[181]}$.

The rs738409 polymorphism of phospholipase domain similar to the patatine containing 3 (PNPLA3) has been reported to be an independent risk factor of HCC in patients with metabolic cirrhosis (odds ratio 1.40$)^{[183]}$. In particular, homozygosity GG was associated with the onset of HCC at a younger age, in patients with a shorter history of cirrhosis. Furthermore, it is associated with a worse prognosis ${ }^{[181]}$. The rs738409 polymorphism seems to alter the export of lipoproteins and lipogenic activity, thus causing the hepatic accumulation of fatty acids with consequent increase of lipid $\beta$-oxidation, as well as the production of ROS, increasing the risk of progression of fibrosis hepatic and HCC development ${ }^{[183]}$. 
An alteration of the intestinal microbiota is often associated with NAFLD and this condition contributes to exacerbating the inflammatory liver ${ }^{[184]}$. In particular, there is the appearance of endotoxinemia that interacts with TLR receptors on Kupffer cells and hepatic stellate cells triggering a cascade of inflammatory signaling causing the production of TNF- $\alpha$, IL-1 $1 \beta$, IL- 6 and $\operatorname{ROS}^{[185]}$. This condition contributes to the progression of liver injury and to carcinogenesis as reported above for ALF.

\section{Pathogenic mechanisms of NAFLD-related HCC}

Most of the HCC secondary to NAFLD occurs in the cirrhotic liver following the mechanism shown above for other etiologies. However, the literature shows a consistent set of evidence on how the development of HCC may also occur in patients without evidence of significant hepatic fibrosis ${ }^{[133,168]}$. As shown in mouse models ${ }^{[186]}$, hepatic steatosis secondary to the metabolic syndrome is a pre-malignant condition, long before cirrhosis. In this regard, obesity and type 2 diabetes mellitus can be considered as independent risk factors for the onset of $\mathrm{HCC}^{[78,172,187]}$.

The pathogenic mechanisms involved in the carcinogenesis of liver cancer in NASH, with or without significant fibrosis, could be related to chronic low-grade inflammation induced by obesity and the metabolic syndrome and mediated by the crucial role of insulin resistance. The development of oxidative stress, lipid peroxidation and mitochondrial damage also play a fundamental pathogenic role. Moreover, it has been shown that alterations of the intestinal microbiota, the presence of gene polymorphism and IR induced hyperinsulinemia can be significant co-factors for the development of NASH and HCC. These data support the concept of "multiple hits hypothesis" in which several factors cooperate in the pathogenesis of NAFLD and HCC ${ }^{[188-190]}$.

The IR, the cornerstone of the metabolic syndrome, is able to induce the onset of HCC by increasing the release of free fatty acids from the adipose tissue and subsequent accumulation in the hepatocytes on one hand and inducing the formation of ROS and subsequent oxidative stress with mitochondrial damage and endoplasmic reticulum dysfunction on the other hand ${ }^{[167]}$. Moreover, IR is able to alter the balance between pro-inflammatory cytokine production (IL- 6 , TNF- $\alpha$, leptin, resistin) and those anti-inflammatory (adiponectin) with a significant increase in pro-inflammatory cytokine ${ }^{[191]}$, leading to a chronic hepatic and systemic inflammatory state. The IR-induced TNF- $\alpha$ stimulation leads to the activation of the nuclear factor Kappa B (NF- $\mathrm{B}$ ) and of the N-terminal kinase c-Jun (JNK) on one side, as well as to the overexpression of tumor growth promotion genes ${ }^{[192]}$ on the other side. The increase in free fatty acids and TNF- $\alpha$ and ROS production are all powerful activators of JNK, overexpressed in more than half of the cases of HCC, which in turn causes the phosphorylation of the substrate-1 of the insulin receptor (IRS-1). The signalling mediated by IRS1 can therefore act as a stimulus for cell survival, promoting the proliferation of hepatocytes through the mitogenated protein kinase and PI3K and inhibiting cell apoptosis by blocking the TGF- $\beta 1^{[193]}$. IR-induced hyperinsulinemia is also able to stimulate the production of growth factors such as IGF-1. All the previously mentioned pathways are able to cause liver inflammation and aberrant stimulation of several genes that are crucial in regulating cell growth and inhibition of apoptosis ${ }^{[175,194]}$.

The cytokinetic imbalance associated with the release of unsaturated fatty acids also contributes to inhibition of tumor suppression factors (for example, phosphatase and homologue of the tensin, PTEN) ${ }^{[195]}$ and inhibition of apoptotic cell abilities ${ }^{[175]}$. In this regard, IR-induced oxidative stress can increase lipid peroxidation, thus leading to the production of trans-4-hydroxy-2-nonenal, which in turn can interact with DNA and cause mutations in the oncosuppressor gene p53, thus favouring hepatocarcinogenesis and the progression of $\mathrm{HCC}^{[196]}$.

The IR-induced increase in TNF- $\alpha$ and IL- 6 also stimulates leptin production ${ }^{[197]}$. The latter acts as a growth factor activating the Janus-activated kinase (JAK), which in turn stimulates signal transducers and activators 
of transcription 3 (STAT3) and extracellular signal-regulated kinases (ERK) ${ }^{[169,198,199]}$. Such leptin-induced pathways represent early events in the promotion of the survival and proliferation of pre-neoplastic cell clones, thus favoring the development of HCC and its invasion and metastasis ${ }^{[198,199]}$. Furthermore, higher levels of leptin are closely related to an increased risk of recurrent HCC after curative treatment ${ }^{[200]}$. On the other hand, IR inhibits the production of adiponectin, an adipokin with anti-inflammatory functions, as well as anti-atherogenic, anti-proliferative, pro-apoptotic, insulin-sensitizing and anti-angiogenic factors ${ }^{[169]}$. In fact, this cytokine is able to stimulate the activation of JNK and induce cell apoptosis ${ }^{[201]}$. Reductions in adiponectin levels appear to be closely associated with the risk of carcinogenesis ${ }^{[202]}$.

Similar to what is observed in ALD, deficiency in the autophagy mechanism is also observable in NAFLD, causing reticuloendothelial damage and cellular oxidative stress and contributing to the formation of an environment suitable for the development of $\mathrm{HCC}^{[203]}$.

The immune system may also participate in the complex multifactorial mechanisms of hepatocarcinogenesis. In fact, the metabolic stress promotes the migration of immune cells in the liver, while the T cells CD8 + and Natural Killer (NK), stimulated by the cell damage caused by NAFLD, interact with the hepatocytes activating the signaling cascades that feed the pre-existing state inflammatory ${ }^{[204]}$. In this way, they can establish a further vicious circle that worsens hepatocyte damage, promoting the progression of NAFLD towards the development of HCC.

\section{DECLARATIONS}

\section{Authors' contributions}

Designed the study: Adinolfi LE

Contributed equally to the search for literature and the writing of the text: Nevola R, Rinaldi L, Giordano M, Marrone A

Reviewed the manuscript: Adinolfi LE, Nevola R

Approved the final version: all authors

\section{Availability of data and materials}

Not applicable.

\section{Financial support and sponsorship}

There was no financial support or sponsorship for this study.

\section{Conflicts of interest}

All authors declare that there are no conflicts of interest.

\section{Ethical approval and consent to participate}

Not applicable.

\section{Consent for publication}

Not applicable.

\section{Copyright}

(c) The Author(s) 2018.

\section{REFERENCES}

1. Global Burden of Disease Liver Cancer Collaboration. The burden of primary liver cancer and underlying etiologies from 1990 to 2015 at the global, regional, and national level: results from the Global Burden of Disease Study 2015. JAMA Oncol 2017;3:1683-91. 
2. Ferlay J, Soerjomataram I, Dikshit R, Eser S, Mathers C, Rebelo M, Parkin DM, Forman D, Bray F. Cancer incidence and mortality worldwide: sources, methods and major patterns in GLOBOCAN 2012. Int J Cancer 2015;136:E359-86.

3. Siegel RL, Miller KD, Jemal A. Cancer statistics, 2018. CA Cancer J Clin 2018;68:7-30.

4. Petrick JL, Braunlin M, Laversanne M, Valery PC, Bray F, McGlynn KA. International trends in liver cancer incidence, overall and by histologic subtype, 1978-2007. Int J Cancer 2016;139:1534-45.

5. Younossi ZM, Koenig AB, Abdelatif D, Fazel Y, Henry L, Wymer M. Global epidemiology of nonalcoholic fatty liver diasease - metaanalytic assessment of prevalence, incidence, and outcomes. Hepatology 2016;64:73-84.

6. Younossi ZM, Otgonsuren M, Henry L, Venkatesan C, Mishra A, Erario M, Hunt S. Association of nonalcoholic fatty liver disease (NAFLD) with hepatocellular carcinoma (HCC) in the United States from 2004 to 2009. Hepatology 2015;62:1723-30.

7. Yang JD, Kim WR, Coelho R, Mettler TA, Benson JT, Sanderson SO, Therneau TM, Kim B, Roberts LR. Cirrhosis is present in most patients with hepatitis B and hepatocellular carcinoma. Clin Gastroenterol Hepatol 2011;9:64-70.

8. Parkin DM. The global health burden of infection-associated cancers in the years 2002. Int J Cancer 2006;118:3030-44.

9. El-Serag HB. Epidemiology of viral hepatitis and hepatocellular carcinoma. Gastroenterology 2012;142:1264-73.e1.

10. Lozano R, Naghavi M, Foreman K, Lim S, Shibuya K, Aboyans V, Abraham J, Adair T, Aggarwal R, Ahn SY, Alvarado M, Anderson HR, Anderson LM, Andrews KG, Atkinson C, Baddour LM, Barker-Collo S, Bartels DH, Bell ML, Benjamin EJ, Bennett D, Bhalla K, Bikbov B, Bin Abdulhak A, Birbeck G, Blyth F, Bolliger I, Boufous S, Bucello C, Burch M, Burney P, Carapetis J, Chen H, Chou D, Chugh SS, Coffeng LE, Colan SD, Colquhoun S, Colson KE, Condon J, Connor MD, Cooper LT, Corriere M, Cortinovis M, de Vaccaro KC, Couser W, Cowie BC, Criqui MH, Cross M, Dabhadkar KC, Dahodwala N, De Leo D, Degenhardt L, Delossantos A, Denenberg J, Des Jarlais DC, Dharmaratne SD, Dorsey ER, Driscoll T, Duber H, Ebel B, Erwin PJ, Espindola P, Ezzati M, Feigin V, Flaxman AD, Forouzanfar MH, Fowkes FG, Franklin R, Fransen M, Freeman MK, Gabriel SE, Gakidou E, Gaspari F, Gillum RF, Gonzalez-Medina D, Halasa YA, Haring D, Harrison JE, Havmoeller R, Hay RJ, Hoen B, Hotez PJ, Hoy D, Jacobsen KH, James SL, Jasrasaria R, Jayaraman S, Johns N, Karthikeyan G, Kassebaum N, Keren A, Khoo JP, Knowlton LM, Kobusingye O, Koranteng A, Krishnamurthi R, Lipnick M, Lipshultz SE, Ohno SL, Mabweijano J, MacIntyre MF, Mallinger L, March L, Marks GB, Marks R, Matsumori A, Matzopoulos R, Mayosi BM, McAnulty JH, McDermott MM, McGrath J, Mensah GA, Merriman TR, Michaud C, Miller M, Miller TR, Mock C, Mocumbi AO, Mokdad AA, Moran A, Mulholland K, Nair MN, Naldi L, Narayan KM, Nasseri K, Norman P, O’Donnell M, Omer SB, Ortblad K, Osborne R, Ozgediz D, Pahari B, Pandian JD, Rivero AP, Padilla RP, Perez-Ruiz F, Perico N, Phillips D, Pierce K, Pope CA 3rd, Porrini E, Pourmalek F, Raju M, Ranganathan D, Rehm JT, Rein DB, Remuzzi G, Rivara FP, Roberts T, De León FR, Rosenfeld LC, Rushton L, Sacco RL, Salomon JA, Sampson U, Sanman E, Schwebel DC, Segui-Gomez M, Shepard DS, Singh D, Singleton J, Sliwa K, Smith E, Steer A, Taylor JA, Thomas B, Tleyjeh IM, Towbin JA, Truelsen T, Undurraga EA, Venketasubramanian N, Vijayakumar L, Vos T, Wagner GR, Wang M, Wang W, Watt K, Weinstock MA, Weintraub R, Wilkinson JD, Woolf AD, Wulf S, Yeh PH, Yip P, Zabetian A, Zheng ZJ, Lopez AD, Murray CJ, AlMazroa MA, Memish ZA. Global and regional mortality from 235 causes of death for 20 age groups in 1990 and 2010: a systematic analysis for the Global Burden of Disease Study 2010. Lancet 2012;380:2095-128.

11. Venook AP, Papandreou C, Furuse J, de Guevara LL. The incidence and epidemiology of hepatocellular carcinoma: a global and regional perspective. Oncologist 2010;15 Suppl 4:5-13.

12. Levrero M, Zucman-Rossi J. Mechanisms of HBV-induced hepatocellular carcinoma. J Hepatol 2016;64:S84-101.

13. Wang SH, Yeh SH, Lin WH, Wang HY, Chen DS, Chen PJ. Identification of androgen response elements in the enhancer I of hepatitis B virus: a mechanism for sex disparity in chronic hepatitis B. Hepatology 2009;50:1392-402.

14. Chen X, Wu F, Liu Y, Lou J, Zhu B, Zou L, Chen W, Gong J, Wang Y, Zhong R. The contribution of serum hepatitis B virus load in the carcinogenesis and prognosis of hepatocellular carcinoma: evidence from two meta-analyses. Oncotarget 2016;7:49299-309.

15. Wang SH, Yeh SH, Lin WH, Yeh KH, Yuan Q, Xia NS, Chen DS, Chen PJ. Estrogen receptor $\alpha$ represses transcription of HBV genes via interaction with hepatocyte nuclearfactor $4 \alpha$. Gastroenterology 2012;142:989-998.e4.

16. Xie Y. Hepatitis B virus-associated hepatocellular carcinoma. Adv Exp Med Biol 2017;1018:11-21.

17. Plentz RR, Park YN, Lechel A, Kim H, Nellessen F, Langkopf BH, Wilkens L, Destro A, Fiamengo B, Manns MP, Roncalli M, Rudolph KL. Telomere shortening and inactivation of cell cycle checkpoints characterize human hepatocarcinogenesis. Hepatology 2007;45:968-76.

18. Kojima H, Yokosuka O, Imazeki F, Saisho H, Omata M. Telomerase activity and telomere length in hepatocellular carcinoma and chronic liver disease. Gastroenterology 1997;112:493-500.

19. El-Serag HB, Tran T, Everhart JE. Diabetes increases the risk of chronic liver disease and hepatocellular carcinoma. Gastroenterology 2004; $126: 460-8$.

20. Yu MC, Yuan JM, Lu SC. Alcohol, cofactors and the genetics of hepatocellular carcinoma. J Gastroenterol Hepatol 2008;23 Suppl 1:S92-7.

21. Marrero JA, Fontana RJ, Fu S, Conjeevaram HS, Su GL, Lok AS. Alcohol, tobacco and obesity are synergistic risk factors for hepatocellular carcinoma. J Hepatol 2005;42:218-24.

22. Zampino R, Pisaturo MA, Cirillo G, Marrone A, Macera M, Rinaldi L, Stanzione M, Durante-Mangoni E, Gentile I, Sagnelli E, Signoriello G, Miraglia Del Giudice E, Adinolfi LE, Coppola N. Hepatocellular carcinoma in chronic HBV-HCV co-infection is correlated to fibrosis and disease duration. Ann Hepatol 2015;14:75-82.

23. Brau N, Fox RK, Xiao P, Marks K, Naqvi Z, Taylor LE, Trikha A, Sherman M, Sulkowski MS, Dieterich DT, Rigsby MO, Wright TL, Hernandez MD, Jain MK, Khatri GK, Sterling RK, Bonacini M, Martyn CA, Aytaman A, Llovet JM, Brown ST, Bini EJ; North American Liver Cancer in HIV Study Group. Presentation and outcome of hepatocellular carcinoma in HIV-infected patients: a U.S.-Canadian multicenter study. J Hepatol 2007;47:527-37.

24. Chan HL, Hui AY, Wong ML, Tse AM, Hung LC, Wong VW, Sung JJ. Genotype C hepatitis B virus infection is associated with an increased risk of hepatocellular carcinoma. Gut 2004;53:1494-8.

25. Lin CL, Kao JH. Natural history of acute and chronic hepatitis B: the role of HBV genotypes and mutants. Best Pract Res Clin Gastroenterol 2017;31:249-55.

26. Datta S, Roychoudhury S, Ghosh A, Dasgupta D, Ghosh A, Chakraborty BC, Ray S, Gupta S, Santra AK, Datta S, Das K, Dhali GK, 
Chowdhury A, Banerjee S. Distinct distribution pattern of hepatitis B virus genotype C and D in liver tissue and serum of dual genotype infected liver cirrhosis and hepatocellular carcinoma patients. PLoS One 2014;9:e102573.

27. Yang HI, Lu SN, Liaw YF, You SL, Sun CA, Wang LY, Hsiao CK, Chen PJ, Chen DS, Chen CJ; Taiwan Community-Based Cancer Screening Project Group. Hepatitis B e antigen and the risk of hepatocellular carcinoma. N Engl J Med 2002;347:168-74.

28. Chen CJ, Yang HI, Su J, Jen CL, You SL, Lu SN, Huang GT, Iloeje UH; REVEAL-HBV Study Group. Risk of hepatocellular carcinoma across a biological gradient of serum hepatitis B virus DNA level. JAMA 2006 Jan 4;295:65-73.

29. Chan KY, Wong CM, Kwan JS, Lee JM, Cheung KW, Yuen MF, Lai CL, Poon RT, Sham PC, Ng IO. Genome-wide association study of hepatocellular carcinoma in Southern Chinese patients with chronic hepatitis B virus infection. PLoS One 2011;6:e28798.

30. Migita K, Miyazoe S, Maeda Y, Daikoku M, Abiru S, Ueki T, Yano K, Nagaoka S, Matsumoto T, Nakao K, Hamasaki K, Yatsuhashi H, Ishibashi H, Eguchi K. Cytokine gene polymorphisms in Japanese patients with hepatitis B virus infection--association between TGF-betal polymorphisms and hepatocellular carcinoma. J Hepatol 2005;42:505-10.

31. Jiang DK, Sun J, Cao G, Liu Y, Lin D, Gao YZ, Ren WH, Long XD, Zhang H, Ma XP, Wang Z, Jiang W, Chen TY, Gao Y, Sun LD, Long JR, Huang HX, Wang D, Yu H, Zhang P, Tang LS, Peng B, Cai H, Liu TT, Zhou P, Liu F, Lin X, Tao S, Wan B, Sai-Yin HX, Qin LX, Yin J, Liu L, Wu C, Pei Y, Zhou YF, Zhai Y, Lu PX, Tan A, Zuo XB, Fan J, Chang J, Gu X, Wang NJ, Li Y, Liu YK, Zhai K, Zhang H, Hu Z, Liu J, Yi Q, Xiang Y, Shi R, Ding Q, Zheng W, Shu XO, Mo Z, Shugart YY, Zhang XJ, Zhou G, Shen H, Zheng SL, Xu J, Yu L. Genetic variants in STAT4 and HLA-DQ genes confer risk of hepatitis B virus-related hepatocellular carcinoma. Nat Genet 2013;45:72-5.

32. Gu X, Qi P, Zhou F, Ji Q, Wang H, Dou T, Zhao Y, Gao C. +49G > A polymorphism in the cytotoxic T-lymphocyte antigen-4 gene increases susceptibility to hepatitis B-related hepatocellular carcinoma in a male Chinese population. Hum Immunol 2010;71:83-7.

33. Yoon YJ, Chang HY, Ahn SH, Kim JK, Park YK, Kang DR, Park JY, Myoung SM, Kim DY, Chon CY, Han KH. MDM2 and p53 polymorphisms are associated with the development of hepatocellular carcinoma in patients with chronic hepatitis B virus infection. Carcinogenesis 2008;29:1192-6.

34. Levrero M, Pollicino T, Petersen J, Belloni L, Raimondo G, Dandri M. Control of cccDNA function in hepatitis B virus infection. J Hepatol 2009;51:581-92.

35. Xie Y. Hepatitis B virus-associated hepatocellular carcinoma. Adv Exp Med Biol 2017;1018:11-21.

36. Ding D, Lou X, Hua D, Yu W, Li L, Wang J, Gao F, Zhao N, Ren G, Li L, Lin B. Recurrent targeted genes of hepatitis B virus in the liver cancer genomes identified by a next-generation sequencing-based approach. PLoS Genet 2012;8:e1003065.

37. Sung WK, Zheng H, Li S, Chen R, Liu X, Li Y, Lee NP, Lee WH, Ariyaratne PN, Tennakoon C, Mulawadi FH, Wong KF, Liu AM, Poon RT, Fan ST, Chan KL, Gong Z, Hu Y, Lin Z, Wang G, Zhang Q, Barber TD, Chou WC, Aggarwal A, Hao K, Zhou W, Zhang C, Hardwick J, Buser C, Xu J, Kan Z, Dai H, Mao M, Reinhard C, Wang J, Luk JM. Genome-wide survey of recurrent HBV integration in hepatocellular carcinoma. Nat Genet 2012;44:765-9.

38. Lau CC, Sun T, Ching AK, He M, Li JW, Wong AM, Co NN, Chan AW, Li PS, Lung RW, Tong JH, Lai PB, Chan HL, To KF, Chan TF, Wong N. Viral-human chimeric transcript predisposes risk to liver cancer development and progression. Cancer Cell 2014;25:335-49.

39. Chotiyaputta W, Lok AS. Hepatitis B virus variants. Nat Rev Gastroenterol Hepatol 2009;6:453-62

40. Liu WC, Wu IC, Lee YC, Lin CP, Cheng JH, Lin YJ, Yen CJ, Cheng PN, Li PF, Cheng YT, Cheng PW, Sun KT, Yan SL, Lin JJ, Yang JC, Chang KC, Ho CH, Tseng VS, Chang BC, Wu JC, Chang TT. Hepatocellular carcinoma-associated single-nucleotide variants and deletions identified by the use of genome-wide high-throughput analysis of hepatitis B virus. J Pathol 2017;243:176-92.

41. Kuang SY, Jackson PE, Wang JB, Lu PX, Muñoz A, Qian GS, Kensler TW, Groopman JD. Specific mutations of hepatitis B virus in plasma predict liver cancer development. Proc Natl Acad Sci U S A 2004;101:3575-80.

42. Liu S, Zhang H, Gu C, Yin J, He Y, Xie J, Cao G. Associations between hepatitis B virus mutations and the risk of hepatocellular carcinoma: a meta-analysis. J Natl Cancer Inst 2009;101:1066-82.

43. Wang HC, Huang W, Lai MD, Su IJ. Hepatitis B virus pre-S mutants, endoplasmic reticulum stress and hepatocarcinogenesis. Cancer Sci 2006;97:683-8.

44. Chen $\mathrm{CH}$, Hung $\mathrm{CH}$, Lee CM, Hu TH, Wang JH, Wang JC, Lu SN, Changchien CS. Pre-S deletion and complex mutations of hepatitis B virus related to advanced liver disease in HBeAg-negative patients. Gastroenterology 2007;133:1466-74.

45. Pollicino T, Cacciola I, Saffioti F, Raimondo G. Hepatitis B virus PreS/S gene variants: pathobiology and clinical implications. J Hepatol 2014;61:408-17.

46. Lee SA, Kim K, Kim H, Kim BJ. Nucleotide change of codon 182 in the surface gene of hepatitis B virus genotype C leading to truncated surface protein is associated with progression of liver diseases. J Hepatol 2012;56:63-9.

47. Lucifora J, Arzberger S, Durantel D, Belloni L, Strubin M, Levrero M, Zoulim F, Hantz O, Protzer U. Hepatitis B virus X protein is essential to initiate and maintain virus replication after infection. J Hepatol 2011;55:996-1003.

48. Belloni L, Pollicino T, De Nicola F, Guerrieri F, Raffa G, Fanciulli M, Raimondo G, Levrero M. Nuclear HBx binds the HBV minichromosome and modifies the epigenetic regulation of cccDNA function. Proc Natl Acad Sci U S A 2009;106:19975-9.

49. Forgues M, Difilippantonio MJ, Linke SP, Ried T, Nagashima K, Feden J, Valerie K, Fukasawa K, Wang XW. Involvement of Crm1 in hepatitis B virus X protein-induced aberrant centriole replication and abnormal mitotic spindles. Mol Cell Biol 2003;23:5282-92.

50. Sanz-Cameno P, Martín-Vílchez S, Lara-Pezzi E, Borque MJ, Salmerón J, Muñoz de Rueda P, Solís JA, López-Cabrera M, Moreno-Otero R. Hepatitis B virus promotes angiopoietin-2 expression in liver tissue: role of HBV x protein. Am J Pathol 2006;169:1215-22.

51. Park SH, Jung JK, Lim JS, Tiwari I, Jang KL. Hepatitis B virus X protein overcomes all-trans retinoic acid-induced cellular senescence by downregulating levels of p16 and p21 via DNA methylation. J Gen Virol 2011;92:1309-17.

52. Levrero M, Zucman-Rossi J. Mechanisms of HBV-induced hepatocellular carcinoma. J Hepatol 2016;64:S84-S101.

53. Khalaf AM, Fuentes D, Morshid AI, Burke MR, Kaseb AO, Hassan M, Hazle JD, Elsayes KM. Role of Wnt/ $\beta$-catenin signaling in hepatocellular carcinoma, pathogenesis, and clinical significance. J Hepatocell Carcinoma 2018;5:61-73.

54. European Association for the Study of the Liver. Electronic address: easloffice@easloffice.eu; European Association for the Study of the Liver. EASL 2017 Clinical Practice Guidelines on the management of hepatitis B virus infection. J Hepatol 2017;67:370-98. 
55. WHO Guidelines Approved by the Guidelines Review Committee. Guidelines for the prevention, care and treatment of persons with chronic hepatitis B infection. Geneva: World Health Organization; 2015.

56. Mason WS, Gill US, Litwin S, Zhou Y, Peri S, Pop O, Hong ML, Naik S, Quaglia A, Bertoletti A, Kennedy PT. HBV-DNA integration and clonal hepatocyte expansion in chronic hepatitis b patients considered immune tolerant. Gastroenterology 2016;151:986-98.e4. d

57. Kim GA, Lim YS, Han S, Choi J, Shim JH, Kim KM, Lee HC, Lee YS. High risk of hepatocellular carcinoma and death in patients with immune-tolerant-phase chronic hepatitis B. Gut 2017;pii: gutjnl-2017-314904.

58. Chang Y, Choe WH, Sinn DH, Lee JH, Ahn SH, Lee H, Shim JJ, Jun DW, Park SY, Nam JY Cho EJ, Yu SJ, Lee DH, Lee JM, Kim YJ, Kwon SY, Paik SW, Yoon JH. Nucleos(t)ide analogue treatment for patients with hepatitis B virus (HBV) e antigen-positive chronic HBV genotype C infection: a nationwide, multicenter, retrospective study. J Infect Dis 2017;216:1407-14.

59. Bertoletti A, Kennedy PTF, Durantel D. HBV infection and HCC: the 'dangerous liaisons'. Gut 2017;pii: gutjnl-2017-315528.

60. Raimondo G, Allain JP, Brunetto MR, Buendia MA, Chen DS, Colombo M, Craxì A, Donato F, Ferrari C, Gaeta GB, Gerlich WH, Levrero M, Locarnini S, Michalak T, Mondelli MU, Pawlotsky JM, Pollicino T, Prati D, Puoti M, Samuel D, Shouval D, Smedile A, Squadrito G, Trépo C, Villa E, Will H, Zanetti AR, Zoulim F. Statements from the Taormina expert meeting on occult hepatitis B virus infection. J Hepatol 2008;49:652-7.

61. Pollicino T, Squadrito G, Cerenzia G, Cacciola I, Raffa G, Craxi A, Farinati F, Missale G, Smedile A, Tiribelli C, Villa E, Raimondo G. Hepatitis B virus maintains its pro-oncogenic properties in the case of occult HBV infection. Gastroenterology 2004;126:102-10.

62. Saitta C, Tripodi G, Barbera A, Bertuccio A, Smedile A, Ciancio A, Raffa G, Sangiovanni A, Navarra G, Raimondo G, Pollicino T. Hepatitis $B$ virus (HBV) DNA integration in patients with occult HBV infection and hepatocellular carcinoma. Liver Int 2015;35:2311-7.

63. Coppola N, Onorato L, Iodice V, Starace M, Minichini C, Farella N, Liorre G, Filippini P, Sagnelli E, de Stefano G. Occult HBV infection in HCC and cirrhotic tissue of HBsAg-negative patients: a virological and clinical study. Oncotarget 2016;7:62706-14.

64. Squadrito G, Cacciola I, Alibrandi A, Pollicino T, Raimondo G. Impact of occult hepatitis B virus infection on the outcome of chronic hepatitis C. J Hepatol 2013;59:696-700.

65. Papatheodoridis GV, Lampertico P, Manolakopoulos S, Lok A. Incidence of hepatocellular carcinoma in chronic hepatitis B patients receiving nucleos(t)ide therapy: a systematic review. J Hepatol 2010;53:348-56.

66. Wu CY, Lin JT, Ho HJ, Su CW, Lee TY, Wang SY, Wu C, Wu JC. Association of nucleos(t)ide analogue therapy with reduced risk of hepatocellular carcinoma in patients with chronic hepatitis B: a nationwide cohort study. Gastroenterology 2014;147:143-151.e5.

67. Lin D, Yang HI, Nguyen N, Hoang J, Kim Y, Vu V, Le A, Chaung K, Nguyen V, Trinh H, Li J, Zhang J, Hsing A, Chen CJ, Nguyen MH. Reduction of chronic hepatitis B-related hepatocellular carcinoma with anti-viral therapy, including low risk patients. Aliment Pharmacol Ther 2016;44:846-55.

68. Hoang JK, Yang HI, Le A, Nguyen NH, Lin D, Vu VD, Chaung K, Nguyen V, Trinh HN, Li J, Zhang JQ, Chen CJ, Nguyen MH. Lower liver cancer risk with antiviral therapy in chronic hepatitis B patients with normal to minimally elevated ALT and no cirrhosis. Medicine (Baltimore) 2016;95:e4433.

69. Lin D, Yang HI, Hoang J, Nguyen MH. Letter: should anti-viral therapy be recommended for individuals chronically infected with hepatitis B virus and at low risk of hepatocellular carcinoma? Authors' reply. Aliment Pharmacol Ther 2017;45:182-3.

70. Fattovich G, Stroffolini T, Zagni I, Donato F. Hepatocellular carcinoma in cirrhosis: incidence and risk factors. Gastroenterology 2004;127:S35-50.

71. European Association for the Study of the Liver; European Organisation for Research and Treatment of Cancer. EASL-EORTC clinical practice guidelines: management of hepatocellular carcinoma. J Hepatol 2012;56:908-43.

72. Lok AS, Seeff LB, Morgan TR, di Bisceglie AM, Sterling RK, Curto TM, Everson GT, Lindsay KL, Lee WM, Bonkovsky HL, Dienstag JL, Ghany MG, Morishima C, Goodman ZD; HALT-C Trial Group. Incidence of hepatocellular carcinoma and associated risk factors in hepatitis C-related advancedliver disease. Gastroenterology 2009;136:138-48.

73. Davis GL, Alter MJ, El-Serag H, Poynard T, Jennings LW. Aging of hepatitis C virus (HCV)-infected persons in the United States: a multiple cohort model of HCV prevalence and disease progression. Gastroenterology 2010;138:513-21, 521.e1-6.

74. Bruno S, Crosignani A, Maisonneuve P, Rossi S, Silini E, Mondelli MU. Hepatitis C virus genotype $1 \mathrm{~b}$ as a major risk factor associated with hepatocellular carcinoma in patients with cirrhosis: a seventeen-year prospective cohort study. Hepatology 2007;46:1350-6.

75. Rinaldi L, Nascimbeni F, Giordano M, Masetti C, Guerrera B, Amelia A, Fascione MC, Ballestri S, Romagnoli D, Zampino R, Nevola R, Baldelli E, Iuliano N, Rosato V, Lonardo A, Adinolfi LE. Clinical features and natural history of cryptogenic cirrhosis compared to hepatitis C virus-related cirrhosis. World J Gastroenterol 2017;23:1458-68.

76. Elkrief L, Chouinard P, Bendersky N, Hajage D, Larroque B, Babany G, Kutala B, Francoz C, Boyer N, Moreau R, Durand F, Marcellin P, Rautou PE, Valla D. Diabetes mellitus is an independent prognostic factor for major liver-related outcomes in patients with cirrhosis and chronic hepatitis C. Hepatology 2014;60:823-31.

77. Cheung O, Sanyal AJ. Hepatitis C infection and nonalcoholic fatty liver disease. Clin Liver Dis 2008;12:573-85, viii-ix.

78. Calle EE, Rodriguez C, Walker-Thurmond K, Thun MJ. Overweight, obesity, and mortality from cancer in a prospectively studied cohort of U.S. adults. N Engl J Med 2003;348:1625-38.

79. Ko C, Siddaiah N, Berger J, Gish R, Brandhagen D, Sterling RK, Cotler SJ, Fontana RJ, McCashland TM, Han SH, Gordon FD, Schilsky ML, Kowdley KV. Prevalence of hepatic iron overload and association with hepatocellular cancer in end-stage liver disease: results from the National Hemochromatosis Transplant Registry. Liver Int 2007;27:1394-401.

80. Lee MH, Yang HI, Lu SN, Jen CL, Yeh SH, Liu CJ, Chen PJ, You SL, Wang LY, Chen WJ, Chen CJ. Hepatitis C virus seromarkers and subsequent risk of hepatocellular carcinoma: long-term predictors from a community-based cohort study. J Clin Oncol 2010;28:4587-93.

81. Duvoux C, Pawlotsky JM, Bastie A, Cherqui D, Soussy CJ, Dhumeaux D. Low HCV replication levels in end-stage hepatitis C virus-related liver disease. J Hepatol 1999;31:593-7.

82. Yates SC, Hafez M, Beld M, Lukashov VV, Hassan Z, Carboni G, Khaled H, McMorrow M, Attia M, Goudsmit J. Hepatocellular carcinoma in Egyptians with and without a history of hepatitis B virus infection: association with hepatitis C virus (HCV) infection but not with (HCV) 
RNA level. Am J Trop Med Hyg 1999;60:714-20.

83. Raimondi S, Bruno S, Mondelli MU, Maisonneuve P. Hepatitis C virus genotype $1 \mathrm{~b}$ as a risk factor for hepatocellular carcinoma development: a meta-analysis. J Hepatol 2009;50:1142-54.

84. Bandiera S, Billie Bian C, Hoshida Y, Baumert TF, Zeisel MB. Chronic hepatitis C virus infection and pathogenesis of hepatocellular carcinoma. Curr Opin Virol 2016;20:99-105.

85. Koike K. Hepatitis $\mathrm{C}$ virus contributes to hepatocarcinogenesis by modulating metabolic and intracellular signaling pathways. J Gastroenterol Hepatol 2007;22 Suppl 1:S108-11.

86. Gieseler RK, Marquitan G, Schlattjan M, Sowa JP, Bechmann LP, Timm J, Roggendorf M, Gerken G, Friedman SL, Canbay A. Hepatocyte apoptotic bodies encasing nonstructural HCV proteins amplify hepatic stellate cell activation: implications for chronic hepatitis C. J Viral Hepat 2011;18:760-7.

87. Matsuzaki K, Murata M, Yoshida K, Sekimoto G, Uemura Y, Sakaida N, Kaibori M, Kamiyama Y, Nishizawa M, Fujisawa J, Okazaki $\mathrm{K}$, Seki T. Chronic inflammation associated with hepatitis $\mathrm{C}$ virus infection perturbs hepatic transforming growth factor beta signaling, promoting cirrhosis and hepatocellular carcinoma. Hepatology 2007;46:48-57.

88. Mesri EA, Feitelson MA, Munger K. Human viral oncogenesis: a cancer hallmarks analysis. Cell Host Microbe 2014;15:266-82.

89. Zemel R, Gerechet S, Greif H, Bachmatove L, Birk Y, Golan-Goldhirsh A, Kunin M, Berdichevsky Y, Benhar I, Tur-Kaspa R. Cell transformation induced by hepatitis C virus NS3 serine protease. J Viral Hepat 2001;8:96-102.

90. Arima N, Kao CY, Licht T, Padmanabhan R, Sasaguri Y, Padmanabhan R. Modulation of cell growth by the hepatitis C virus nonstructural protein NS5A. J Biol Chem 2001;276:12675-84.

91. Fukutomi T, Zhou Y, Kawai S, Eguchi H, Wands JR, Li J. Hepatitis C virus core protein stimulates hepatocyte growth: correlation with upregulation of wnt-1 expression. Hepatology 2005;41:1096-105.

92. Zhao LJ, Wang L, Ren H, Cao J, Li L, Ke JS, Qi ZT. Hepatitis C virus E2 protein promotes human hepatoma cell proliferation through the MAPK/ERK signaling pathway via cellular receptors. Exp Cell Res 2005;305:23-32.

93. Lai CK, Jeng KS, Machida K, Cheng YS, Lai MM. Hepatitis C virus NS3/4A protein interacts with ATM, impairs DNA repair and enhances sensitivity to ionizing radiation. Virology 2008;370:295-309.

94. Okuda M, Li K, Beard MR, Showalter LA, Scholle F, Lemon SM, Weinman SA. Mitochondrial injury, oxidative stress, and antioxidant gene expression are induced by hepatitis $C$ virus core protein. Gastroenterology. 2002;122:366-75.

95. Fujinaga H, Tsutsumi T, Yotsuyanagi H, Moriya K, Koike K. Hepatocarcinogenesis in hepatitis C: HCV shrewdly exacerbates oxidative stress by modulating both production and scavenging of reactive oxygen species. Oncology 2011;81 Suppl 1:11-7.

96. Moriya K, Nakagawa K, Santa T, Shintani Y, Fujie H, Miyoshi H, Tsutsumi T, Miyazawa T, Ishibashi K, Horie T, Imai K, Todoroki T, Kimura S, Koike K. Oxidative stress in the absence of inflammation in a mouse model for hepatitis $\mathrm{C}$ virus-associated hepatocarcinogenesis. Cancer Res 2001;61:4365-70.

97. Machida K, Tsukamoto H, Liu JC, Han YP, Govindarajan S, Lai MM, Akira S, Ou JH. c-Jun mediates hepatitis C virus hepatocarcinogenesis through signal transducer and activator of transcription 3 and nitric oxide-dependent impairment of oxidative DNA repair. Hepatology 2010;52:480-92.

98. Tsutsumi T, Suzuki T, Moriya K, Yotsuyanagi H, Shintani Y, Fujie H, Matsuura Y, Kimura S, Koike K, Miyamura T. Alteration of intrahepatic cytokine expression and AP-1 activation in transgenic mice expressing hepatitis C virus core protein. Virology 2002;304:41524

99. Tsutsumi T, Suzuki T, Moriya K, Shintani Y, Fujie H, Miyoshi H, Matsuura Y, Koike K, Miyamura T. Hepatitis C virus core protein activates ERK and p38 MAPK in cooperation with ethanol in transgenic mice. Hepatology 2003;38:820-8.

100. Alisi A, Giambartolomei S, Cupelli F, Merlo P, Fontemaggi G, Spaziani A, Balsano C. Physical and functional interaction between HCV core protein and the different p73 isoforms. Oncogene 2003;22:2573-80.

101. Moriya K, Fujie H, Shintani Y, Yotsuyanagi H, Tsutsumi T, Ishibashi K, Matsuura Y, Kimura S, Miyamura T, Koike K. The core protein of hepatitis C virus induces hepatocellular carcinoma in transgenic mice. Nat Med 1998;4:1065-7.

102. Tovar V, Alsinet C, Villanueva A, Hoshida Y, Chiang DY, Solé M, Thung S, Moyano S, Toffanin S, Mínguez B, Cabellos L, Peix J, Schwartz M, Mazzaferro V, Bruix J, Llovet JM. IGF activation in a molecular subclass of hepatocellular carcinoma and pre-clinical efficacy of IGF-1R blockage. J Hepatol 2010;52:550-9.

103. Aytug S, Reich D, Sapiro LE, Bernstein D, Begum N. Impaired IRS-1/PI3-kinase signaling in patients with HCV: a mechanism for increased prevalence of type 2 diabetes. Hepatology 2003;38:1384-92.

104. Desbois AC, Cacoub P. Diabetes mellitus, insulin resistance and hepatitis C virus infection: a contemporary review. World J Gastroentero 2017;23:1697-1711.

105. Irshad M, Gupta P, Irshad K. Molecular basis of hepatocellular carcinoma induced by hepatitis C virus infection. World J Hepatol 2017;9:1305-14.

106. Elkrief L, Chouinard P, Bendersky N, Hajage D, Larroque B, Babany G, Kutala B, Francoz C, Boyer N, Moreau R, Durand F, Marcellin P, Rautou PE, Valla D. Diabetes mellitus is an independent prognostic factor for major liver-related outcomes in patients with cirrhosis and chronic hepatitis C. Hepatology 2014;60:823-31.

107. Ikeda A, Shimizu T, Matsumoto Y, Fujii Y, Eso Y, Inuzuka T, Mizuguchi A, Shimizu K2, Hatano E, Uemoto S, Chiba T, Marusawa H. Leptin receptor somatic mutations are frequent in $\mathrm{HCV}$-infected cirrhotic liver and associated with hepatocellular carcinoma. Gastroenterology 2014;146:222-32.e35.

108. Rehermann B. Pathogenesis of chronic viral hepatitis: differential roles of T cells and NK cells. Nat Med 2013;19:859-68.

109. van der Meer AJ, Veldt BJ, Feld JJ, Wedemeyer H, Dufour JF, Lammert F, Duarte-Rojo A, Heathcote EJ, Manns MP, Kuske L, Zeuzem S, Hofmann WP, de Knegt RJ, Hansen BE, Janssen HL. Association between sustained virological response and all-cause mortality among patients with chronic hepatitis $C$ and advanced hepatic fibrosis. JAMA $2012 ; 308: 2584-93$.

110. Innes HA, McDonald SA, Dillon JF, Allen S, Hayes PC, Goldberg D, Mills PR, Barclay ST, Wilks D, Valerio H, Fox R, Bhattacharyya D, 
Kennedy N, Morris J, Fraser A, Stanley AJ, Bramley P, Hutchinson SJ. Toward a more complete understanding of the association between a hepatitis C sustained viralresponse and cause-specific outcomes. Hepatology 2015;62:355-64.

111. Nahon P, Bourcier V, Layese R, Audureau E, Cagnot C, Marcellin P, Guyader D, Fontaine H, Larrey D, De Lédinghen V, Ouzan D, Zoulim F, Roulot D, Tran A, Bronowicki JP, Zarski JP, Leroy V, Riachi G, Calès P, Péron JM, Alric L, Bourlière M, Mathurin P, Dharancy S, Blanc JF, Abergel A, Serfaty L, Mallat A, Grangé JD, Attali P, Bacq Y, Wartelle C, Dao T, Benhamou Y, Pilette C, Silvain C, Christidis C, Capron D, Bernard-Chabert B, Zucman D, Di Martino V, Thibaut V, Salmon D, Ziol M, Sutton A, Pol S, Roudot-Thoraval F; ANRS CO12 CirVir Group. Eradication of hepatitis C virus infection in patients with cirrhosis reduces risk of liver and non-liver complications. Gastroenterology 2017;152:142-156.e2.

112. Roche B, Coilly A, Duclos-Vallee JC, Samuel D. The impact of treatment of hepatitis C with DAAs on the occurrence of HCC. Liver Int 2018;38 Suppl 1:139-45.

113. Waziry R, Hajarizadeh B, Grebely J, Amin J, Law M, Danta M, George J, Dore GJ. Hepatocellular carcinoma risk following direct-acting antiviral HCV therapy: a systematic review, meta-analyses, and meta-regression. J Hepatol 2017;67:1204-12.

114. Ioannou GN, Green PK, Berry K. HCV eradication induced by direct-acting antiviral agents reduces the risk of hepatocellular carcinoma. J Hepatol 2017; pii: S0168-8278(17)32273-0.

115. Kanwal F, Kramer J, Asch SM, Chayanupatkul M, Cao Y, El-Serag HB. Risk of hepatocellular cancer in HCV patients treated with directacting antiviral agents. Gastroenterology 2017;153:996-1005.e1.

116. Ramadori P, Cubero FJ, Liedtke C, Trautwein C, Nevzorova YA. Alcohol and hepatocellular carcinoma: adding fuel to the flame. Cancers (Basel) 2017;9. pii: E130.

117. Blonski W, Kotlyar DS, Forde KA. Non-viral causes of hepatocellular carcinoma. World J Gastroenterol 2010;16:3603-15.

118. Mancebo A, González-Diéguez ML, Cadahía V, Varela M, Pérez R, Navascués CA, Sotorríos NG, Martínez M, Rodrigo L, Rodríguez M. Annual incidence of hepatocellular carcinoma among patients with alcoholic cirrhosis and identification of risk groups. Clin Gastroenterol Hepatol;11:95-101.

119. Marot A, Henrion J, Knebel JF, Moreno C, Deltenre P. Alcoholic liver disease confers a worse prognosis than HCV infection and nonalcoholic fatty liver disease among patients with cirrhosis: An observational study. PLoS One 2017;12:e0186715.

120. Donato F, Tagger A, Gelatti U, Parrinello G, Boffetta P, Albertini A, Decarli A, Trevisi P, Ribero ML, Martelli C, Porru S, Nardi G. Alcohol and hepatocellular carcinoma: the effect of lifetime intake and hepatitis virus infections in men and women. Am J Epidemiol 2002;155:32331.

121. Persson EC, Schwartz LM, Park Y, Trabert B, Hollenbeck AR, Graubard BI, Freedman ND, McGlynn KA. Alcohol consumption, folate intake, hepatocellular carcinoma, and liver disease mortality. Cancer Epidemiol Biomarkers Prev 2013;22:415-21.

122. Matsuhashi T, Yamada N, Shinzawa H, Takahashi T. Effect of alcohol on tumor growth of hepatocellular carcinoma with type C cirrhosis. Intern Med 1996;35:443-8

123. Poynard T, Mathurin P, Lai CL, Guyader D, Poupon R, Tainturier MH, Myers RP, Muntenau M, Ratziu V, Manns M, Vogel A, Capron F, Chedid A, Bedossa P; PANFIBROSIS Group. A comparison of fibrosis progression in chronic liver diseases. J Hepatol 2003;38:257-65.

124. Heckley GA, Jarl J, Asamoah BO, G-Gerdtham U. How the risk of liver cancer changes after alcohol cessation: a review and meta-analysis of the current literature. BMC Cancer 2011;11:446.

125. Joshi K, Kohli A, Manch R, Gish R. Alcoholic liver disease: high risk or low risk for developing hepatocellular carcinoma? Clin Liver Dis 2016;20:563-80.

126. Galati G, Dell’Unto C, Vespasiani-Gentilucci U, Vincentis A, Gallo P, Guidi A, Picardi A. Hepatocellular carcinoma in alcoholic liver disease: current management and recent advances. Rev Recent Clin Trials 2016;11:238-52.

127. Salameh H, Raff E, Erwin A, Seth D, Nischalke HD, Falleti E, Burza MA, Leathert J, Romeo S, Molinaro A, Corradini SG, Toniutto P, Spengler U, Daly A, Day CP, Kuo YF, Singal AK. PNPLA3 gene polymorphism is associated with predisposition to and severity of alcoholic liver disease. Am J Gastroenterol 2015 Jun;110:846-56.

128. Nahon P, Nault JC. Constitutional and functional genetics of human alcohol-related hepatocellular carcinoma. Liver Int 2017;37:1591-1601.

129. Purohit V, Rapaka R, Kwon OS, Song BJ. Roles of alcohol and tobacco exposure in the development of hepatocellular carcinoma. Life Sci 2013;92:3-9.

130. Loomba R, Yang HI, Su J, Brenner D, Barrett-Connor E, Iloeje U, Chen CJ. Synergism between obesity and alcohol in increasing the risk of hepatocellular carcinoma: a prospective cohort study. Am J Epidemiol 2013;177:333-42.

131. Grewal P, Viswanathen VA. Liver cancer and alcohol. Clin Liver Dis 2012;16:839-50.

132. Hassan MM, Hwang LY, Hatten CJ, Swaim M, Li D, Abbruzzese JL, Beasley P, Patt YZ. Risk factors for hepatocellular carcinoma: synergism of alcohol with viral hepatitis and diabetes mellitus. Hepatology 2002;36:1206-13.

133. Yasui K, Hashimoto E, Komorizono Y, Koike K, Arii S, Imai Y, Shima T, Kanbara Y, Saibara T, Mori T, Kawata S, Uto H, Takami S, Sumida Y, Takamura T, Kawanaka M, Okanoue T; Japan NASH Study Group, Ministry of Health, Labour, and Welfare of Japan. Characteristics of patients with nonalcoholic steatohepatitis who develop hepatocellular carcinoma. Clin Gastroenterol Hepatol 2011;9:42833.

134. N'Kontchou G, Paries J, Htar MT, Ganne-Carrie N, Costentin L, Grando-Lemaire V, Trinchet JC, Beaugrand M. Risk factors for hepatocellular carcinoma in patients with alcoholic or viral C cirrhosis. Clin Gastroenterol Hepatol 2006;4:1062-8.

135. Torisu Y, Ikeda K, Kobayashi M, Hosaka T, Sezaki H, Akuta N, Kawamura Y, Yatsuji H, Suzuki F, Suzuki Y, Arase Y, Kumada H. Diabetes mellitus increases the risk of hepatocarcinogenesis in patients with alcoholic cirrhosis: a preliminary report. Hepatol Res 2007;37:517-23.

136. Yuan JM, Govindarajan S, Arakawa K, Yu MC. Synergism of alcohol, diabetes, and viral hepatitis on the risk of hepatocellular carcinoma in blacks and whites in the U.S. Cancer 2004;101:1009-17.

137. Lin CW, Lin CC, Mo LR, Chang CY, Perng DS, Hsu CC, Lo GH, Chen YS, Yen YC, Hu JT, Yu ML, Lee PH, Lin JT, Yang SS. Heavy alcohol consumption increases the incidence of hepatocellular carcinoma in hepatitis B virus-related cirrhosis. J Hepatol 2013;58:730-5.

138. Chung NS, Kwon OS, Park CH, Kim YN, Cho GH, Lee JJ, Kim GH, Kim HO, Ko KI, Yu SK, Kwon KA, Kim YS, Choi DJ, Kim JH. 
A comparative cross-sectional study of the development of hepatocellular carcinoma in patients with liver cirrhosis caused by hepatitis B virus, alcohol, or combination of hepatitis b virus and alcohol. Korean J Gastroenterol 2007;49:369-75.

139. Kwon OS, Jung YK, Bae KS, Kim JH, Kim SG, Kim YS, Lee JI, Lee JW, Kim YS. Anti-hepatitis B core positivity as a risk factor for hepatocellular carcinoma in alcoholic cirrhosis: a case-control study. Alcohol 2012;46:537-41.

140. Uetake S, Yamauchi M, Itoh S, Kawashima O, Takeda K, Ohata M. Analysis of risk factors for hepatocellular carcinoma in patients with HBs antigen- and anti-HCV antibody-negative alcoholic cirrhosis: clinical significance of prior hepatitis B virus infection. Alcohol Clin Exp Res 2003;27(8 Suppl):47S-51S.

141. Aizawa Y, Shibamoto Y, Takagi I, Zeniya M, Toda G. Analysis of factors affecting the appearance of hepatocellular carcinoma in patients with chronic hepatitis C. A long term follow-up study after histologic diagnosis. Cancer 2000;89:53-9.

142. Tsutsumi M, Ishizaki M, Takada A. Relative risk for the development of hepatocellular carcinoma in alcoholic patients with cirrhosis: a multiple logistic-regression coefficient analysis. Alcohol Clin Exp Res 1996;20:758-62.

143. Fletcher LM, Dixon JL, Purdie DM, Powell LW, Crawford DH. Excess alcohol greatly increases the prevalence of cirrhosis in hereditary hemochromatosis. Gastroenterology 2002;122:281-9.

144. Zhao C, Liu Y, Xiao J, Liu L, Chen S, Mohammadi M, McClain CJ, Li X, Feng W. FGF21 mediates alcohol-induced adipose tissue lipolysis by activation of systemic release of catecholamine in mice. J Lipid Res 2015;56:1481-91.

145. Mahli A, Hellerbrand C. Alcohol and obesity: a dangerous association for fatty liver disease. Dig Dis 2016;34 Suppl 1:32-9.

146. Kong L, Ren W, Li W, Zhao S, Mi H, Wang R, Zhang Y, Wu W, Nan Y, Yu J. Activation of peroxisome proliferator activated receptor alpha ameliorates ethanol induced steatohepatitis in mice. Lipids Health Dis 2011;10:246.

147. Zhang W, Sun Q, Zhong W, Sun X, Zhou Z. Hepatic peroxisome proliferator-activated receptor gamma signaling contributes to alcoholinduced hepatic steatosis and inflammation in mice. Alcohol Clin Exp Res 2016;40:988-99.

148. Testino G, Leone S, Borro P. Alcohol and hepatocellular carcinoma: a review and a point of view. World J Gastroenterol 2014;20:15943-54.

149. Ramadori P, Cubero FJ, Liedtke C, Trautwein C, Nevzorova YA. Alcohol and hepatocellular carcinoma: adding fuel to the flame. Cancers (Basel) 2017;9: pii: E130

150. Kohgo Y, Ohtake T, Ikuta K, Suzuki Y, Hosoki Y, Saito H, Kato J. Iron accumulation in alcoholic liver diseases. Alcohol Clin Exp Res 2005;29 (11 Suppl):189S-93S

151. Eid N, Ito Y, Otsuki Y. Ethanol-induced hepatic autophagy: friend or foe? World J Hepatol 2015;7:1154-6.

152. Lambert MP, Paliwal A, Vaissière T, Chemin I, Zoulim F, Tommasino M, Hainaut P, Sylla B, Scoazec JY, Tost J, Herceg Z. Aberrant DNA methylation distinguishes hepatocellular carcinoma associated with HBV and HCV infection and alcohol intake. J Hepatol 2011;54:705-15.

153. Mandrekar P, Szabo G. Signalling pathways in alcohol-induced liver inflammation. J Hepatol 2009;50:1258-66.

154. Uthaya Kumar DB, Chen CL, Liu JC, Feldman DE, Sher LS, French S, DiNorcia J, French SW, Naini BV, Junrungsee S, Agopian VG, Zarrinpar A, Machida K. TLR4 signaling via NANOG cooperates with STAT3 to activate Twist1 and promote formation of tumor-initiating stem-like cells in livers of mice. Gastroenterology 2016;150:707-19.

155. Chen CL, Uthaya Kumar DB, Punj V, Xu J, Sher L, Tahara SM, Hess S, Machida K. NANOG metabolically reprograms tumor-initiating stem-like cells through tumorigenic changes in oxidative phosphorylation and fatty acid metabolism. Cell Metab 2016;23:206-19.

156. Dapito DH, Mencin A, Gwak GY, Pradere JP, Jang MK, Mederacke I, Caviglia JM, Khiabanian H, Adeyemi A, Bataller R, Lefkowitch JH, Bower M, Friedman R, Sartor RB, Rabadan R, Schwabe RF. Promotion of hepatocellular carcinoma by the intestinal microbiota and TLR4 Cancer Cell 2012;21:504-16.

157. Pavanello S, Hoxha M, Dioni L, Bertazzi PA, Snenghi R, Nalesso A, Ferrara SD, Montisci M, Baccarelli A. Shortened telomeres in individuals with abuse in alcohol consumption. Int J Cancer 2011;129:983-92.

158. Farazi PA, DePinho RA. Hepatocellular carcinoma pathogenesis: from genes to environment. Nat Rev Cancer 2006;6:674-87.

159. Wang XD, Liu C, Chung J, Stickel F, Seitz HK, Russell RM. Chronic alcohol intake reduces retinoic acid concentration and enhances AP-1 (c-Jun and c-Fos) expression in rat liver. Hepatology 1998;28:744-50.

160. Napoli JL. Effects of ethanol on physiological retinoic acid levels. IUBMB Life 2011;63:701-6.

161. Ishijima N, Kanki K, Shimizu H, Shiota G. Activation of AMP-activated protein kinase by retinoic acid sensitizes hepatocellular carcinoma cells to apoptosis induced by sorafenib. Cancer Sci 2015;106:567-75.

162. Ascha MS, Hanouneh IA, Lopez R, Tamimi TA, Feldstein AF, Zein NN. The incidence and risk factors of hepatocellular carcinoma in patients with nonalcoholic steatohepatitis. Hepatology 2010;51:1972-8.

163. Ertle J, Dechêne A, Sowa JP, Penndorf V, Herzer K, Kaiser G, Schlaak JF, Gerken G, Syn WK, Canbay A. Non-alcoholic fatty liver disease progresses to hepatocellular carcinoma in the absence of apparent cirrhosis. Int J Cancer 2011;128:2436-43.

164. Paradis V, Zalinski S, Chelbi E, Guedj N, Degos F, Vilgrain V, Bedossa P, Belghiti J. Hepatocellular carcinomas in patients with metabolic syndrome often develop without significant liver fibrosis: a pathological analysis. Hepatology 2009;49:851-9.

165. Baffy G, Brunt EM, Caldwell SH. Hepatocellular carcinoma in non-alcoholic fatty liver disease: an emerging menace. J Hepatol 2012;56:1384-91.

166. White DL, Kanwal F, El-Serag HB. Association between nonalcoholic fatty liver disease and risk for hepatocellular cancer, based on systematic review. Clin Gastroenterol Hepatol 2012;10:1342-59.e2.

167. Mittal S, El-Serag HB, Sada YH, Kanwal F, Duan Z, Temple S, May SB, Kramer JR, Richardson PA, Davila JA. Hepatocellular carcinoma in the absence of cirrhosis in United States veterans is associated with nonalcoholic fatty liver disease. Clin Gastroenterol Hepatol 2016;14:124-31.e1.

168. Piscaglia F, Svegliati-Baroni G, Barchetti A, Pecorelli A, Marinelli S, Tiribelli C, Bellentani S; HCC-NAFLD Italian Study Group. Clinical patterns of hepatocellular carcinoma in nonalcoholic fatty liver disease: a multicenter prospective study. Hepatology 2016;63:827-38.

169. Said A, Ghufran A. Epidemic of non-alcoholic fatty liver disease and hepatocellular carcinoma. World J Clin Oncol 2017;8:429-36.

170. Than NN, Ghazanfar A, Hodson J, Tehami N, Coldham C, Mergental H, Manas D, Shah T, Newsome PN, Reeves H, Shetty S. Comparing clinical presentations, treatments and outcomes of hepatocellular carcinoma due to hepatitis $\mathrm{C}$ and non-alcoholic fatty liver disease. QJM 
2017;110:73-81.

171. Larsson SC, Wolk A. Overweight, obesity and risk of liver cancer: a meta-analysis of cohort studies. Br J Cancer 2007;97:1005-8.

172. Raff EJ, Kakati D, Bloomer JR, Shoreibah M, Rasheed K, Singal AK. Diabetes mellitus predicts occurrence of cirrhosis and hepatocellular cancer in alcoholic liver and non-alcoholic fatty liver diseases. J Clin Transl Hepatol 2015;3:9-16.

173. Davila JA, Morgan RO, Shaib Y, McGlynn KA, El-Serag HB. Diabetes increases the risk of hepatocellular carcinoma in the United States: a population based case control study. Gut 2005;54:533-9.

174. Polesel J, Zucchetto A, Montella M, Dal Maso L, Crispo A, La Vecchia C, Serraino D, Franceschi S, Talamini R. The impact of obesity and diabetes mellitus on the risk of hepatocellular carcinoma. Ann Oncol 2009;20:353-7.

175. Starley BQ, Calcagno CJ, Harrison SA. Nonalcoholic fatty liver disease and hepatocellular carcinoma: a weighty connection. Hepatology 2010;51:1820-32.

176. Adinolfi LE, Rinaldi L, Guerrera B, Restivo L, Marrone A, Giordano M, Zampino R. NAFLD and NASH in HCV infection: prevalence and significance in hepatic and extrahepatic manifestations. Int J Mol Sci. 2016 May 25;17;pii: E803.

177. Weinmann A, Alt Y, Koch S, Nelles C, Düber C, Lang H, Otto G, Zimmermann T, Marquardt JU, Galle PR, Wörns MA, Schattenberg JM. Treatment and survival of non-alcoholic steatohepatitis associated hepatocellular carcinoma. BMC Cancer 2015;15:210.

178. Giannini EG, Marabotto E, Savarino V, Trevisani F, di Nolfo MA, Del Poggio P, Benvegnù L, Farinati F, Zoli M, Borzio F, Caturelli E, Chiaramonte M; Italian Liver Cancer (ITALICA) Group. Hepatocellular carcinoma in patients with cryptogenic cirrhosis. Clin Gastroenterol Hepatol 2009;7:580-5.

179. White DL, Kanwal F, El-Serag HB. Association between nonalcoholic fatty liver disease and risk for hepatocellular cancer, based on systematic review. Clin Gastroenterol Hepatol 2012;10:1342-1359.e2.

180. Singal AG, Yopp AC, Gupta S, Skinner CS, Halm EA, Okolo E, Nehra M, Lee WM, Marrero JA, Tiro JA. Failure rates in the hepatocellular carcinoma surveillance process. Cancer Prev Res (Phila) 2012;5:1124-30.

181. Younes R, Bugianesi E. Should we undertake surveillance for HCC in patients with NAFLD? J Hepatol 2018 Feb;68:326-334.

182. Uppot RN, Sahani DV, Hahn PF, Gervais D, Mueller PR. Impact of obesity on medical imaging and image-guided intervention. AJR Am J Roentgenol 2007;188:433-40.

183. Singal AG, Manjunath H, Yopp AC, Beg MS, Marrero JA, Gopal P, Waljee AK. The effect of PNPLA3 on fibrosis progression and development of hepatocellular carcinoma: a meta-analysis. Am J Gastroenterol 2014;109:325-34.

184. Gangarapu V, Yildiz K, Ince AT, Baysal B. Role of gut microbiota: obesity and NAFLD. Turk J Gastroenterol 2014;25:133-40.

185. Borrelli A, Bonelli P, Tuccillo FM, Goldfine ID, Evans JL, Buonaguro FM, Mancini A. Role of gut microbiota and oxidative stress in the progression of non-alcoholic fatty liver disease to hepatocarcinoma: current and innovative therapeutic approaches. Redox Biol 2018;15:467-79.

186. Yang S, Lin HZ, Hwang J, Chacko VP, Diehl AM. Hepatic hyperplasia in noncirrhotic fatty livers: is obesity-related hepatic steatosis a premalignant condition? Cancer Res 2001;61:5016-23.

187. El-Serag HB, Hampel H, Javadi F. The association between diabetes and hepatocellular carcinoma: a systematic review of epidemiologic evidence. Clin Gastroenterol Hepatol 2006;4:369-80.

188. Tilg H, Moschen AR. Evolution of inflammation in nonalcoholic fatty liver disease: the multiple parallel hits hypothesis. Hepatology 2010;52:1836-46.

189. Takaki A, Kawai D, Yamamoto K. Multiple hits, including oxidative stress, as pathogenesis and treatment target in non-alcoholic steatohepatitis (NASH). Int J Mol Sci 2013;14:20704-28.

190. Lonardo A, Nascimbeni F, Maurantonio M, Marrazzo A, Rinaldi L, Adinolfi LE. Nonalcoholic fatty liver disease: evolving paradigms. World J Gastroenterol 2017;23:6571-92.

191. Perumpail RB, Liu A, Wong RJ, Ahmed A, Harrison SA. Pathogenesis of hepatocarcinogenesis in non-cirrhotic nonalcoholic fatty liver disease: Potential mechanistic pathways. World J Hepatol 2015;7:2384-8.

192. Stickel F, Hellerbrand C. Non-alcoholic fatty liver disease as a risk factor for hepatocellular carcinoma: mechanisms and implications. Gut 2010;59:1303-7.

193. Gu J, Yao M, Yao D, Wang L, Yang X, Yao D. Nonalcoholic lipid accumulation and hepatocyte malignant transformation. J Clin Transl Hepatol 2016;4:123-30.

194. Page JM, Harrison SA. NASH and HCC. Clin Liver Dis 2009;13:631-47.

195. Vinciguerra M, Sgroi A, Veyrat-Durebex C, Rubbia-Brandt L, Buhler LH, Foti M. Unsaturated fatty acids inhibit the expression of tumor suppressor phosphatase and tensin homolog (PTEN) via microRNA-21 up-regulation in hepatocytes. Hepatology 2009;49:1176-84.

196. Hu W, Feng Z, Eveleigh J, Iyer G, Pan J, Amin S, Chung FL, Tang MS. The major lipid peroxidation product, trans-4-hydroxy-2nonenal, preferentially forms DNA adducts at codon 249 of human p53 gene, a unique mutational hotspot in hepatocellular carcinoma. Carcinogenesis 2002;23:1781-9.

197. Angulo P, Alba LM, Petrovic LM, Adams LA, Lindor KD, Jensen MD. Leptin, insulin resistance, and liver fibrosis in human nonalcoholic fatty liver disease. J Hepatol 2004;41:943-9.

198. Fenton JI, Hursting SD, Perkins SN, Hord NG. Interleukin-6 production induced by leptin treatment promotes cell proliferation in an Apc $(\mathrm{Min} /+)$ colon epithelial cell line. Carcinogenesis. 2006;27:1507-15.

199. Saxena NK, Sharma D, Ding X, Lin S, Marra F, Merlin D, Anania FA. Concomitant activation of the JAK/STAT, PI3K/AKT, and ERK signaling is involved in leptin-mediated promotion of invasion and migration of hepatocellular carcinoma cells. Cancer Res 2007;67:2497507.

200. Watanabe N, Takai K, Imai K, Shimizu M, Naiki T, Nagaki M, Moriwaki H. Increased levels of serum leptin are a risk factor for the recurrence of stage I/II hepatocellular carcinoma after curative treatment. J Clin Biochem Nutr 2011;49:153-8.

201. Jiang CM, Pu CW, Hou YH, Chen Z, Alanazy M, Hebbard L. Non alcoholic steatohepatitis a precursor for hepatocellulae carcinoma developmant. World J Gastroenterol 2014 28;20:16464-73. 
202. Dalamaga M, Diakopoulos KN, Mantzoros CS. The role of adiponectin in cancer: a review of current evidence. Endocr Rev 2012;33:54794.

203. Yang L, Li P, Fu S, Calay ES, Hotamisligil GS. Defective hepatic autophagy in obesity promotes ER stress and causes insulin resistance. Cell Metab 2010;11:467-78.

204. Wolf MJ, Adili A, Piotrowitz K, Abdullah Z, Boege Y, Stemmer K, Ringelhan M, Simonavicius N, Egger M, Wohlleber D, Lorentzen A, Einer C, Schultz S, Clavel T, Protzer U, Thiele C, Zischka H, Moch H, Tschöp M, Tumanov AV, Haller D, Unger K, Karin M, Kopf M, Knolle P, Weber A, Heikenwalder M. Metabolic activation of intrahepatic CD8+ T cells and NKT cells causes nonalcoholic steatohepatatis and liver cancer via cross-talk with hepatocytes. Cancer Cell 2014;26:549-64. 